الدور الاقتصادي لربة الأسرة العاملة السعودية وعلاقته بالتوافق الزواجي

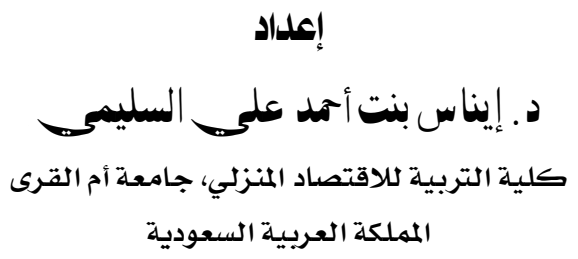

مجلة بحوث التربية النوعية - جامعة المنصورة

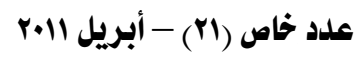




\section{الدور الاقتصادي لربة الأسرة العاملة السعودية وعلاقته بالتوافق الزواجي}

$$
\text { إعداد }
$$

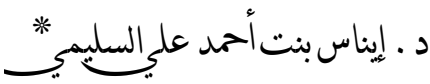

\section{|ll|}

استهدف هذا البحث:الكشف عن العلاقة بين الدور الاقتصادي لريبة الأسـرة العاملـة وتحقيق العاديق

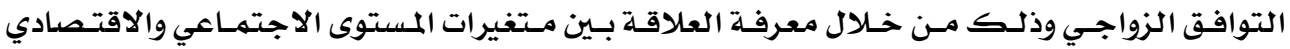

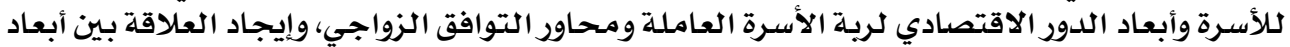

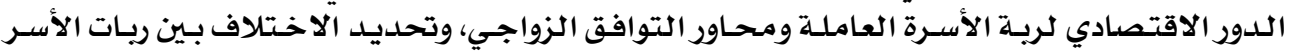

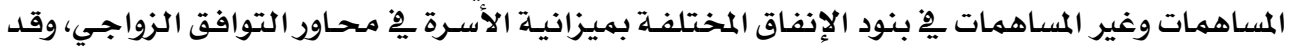

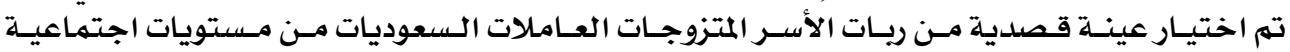

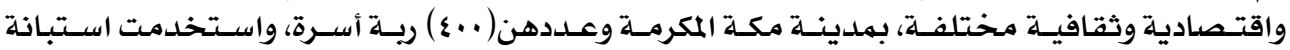

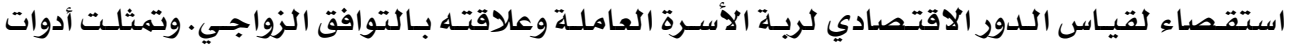

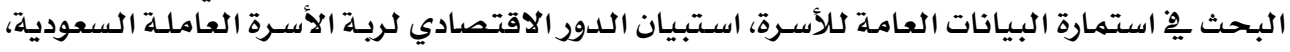

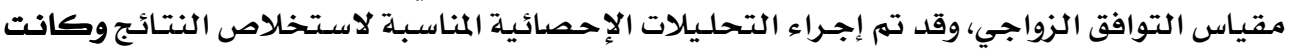

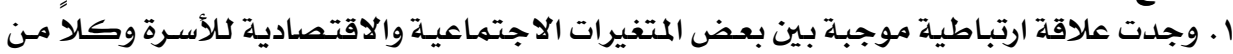
أهم النتائج:

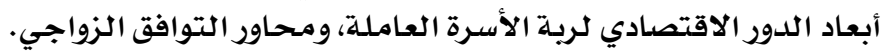

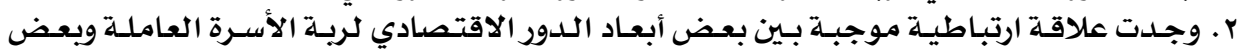

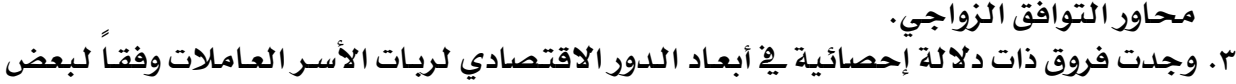

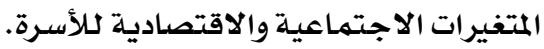

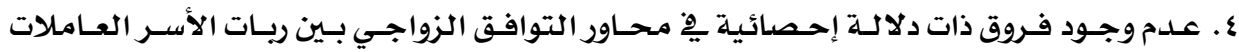

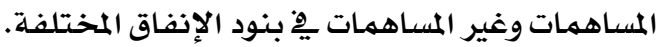
وأوصت الباحثة بالتوصيات المبات التالية:

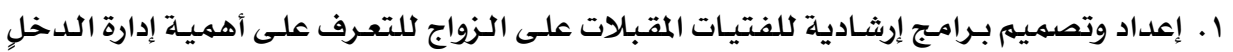

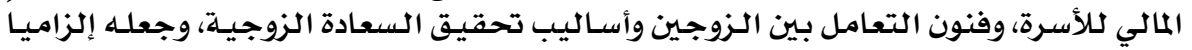
قبل عقد القران.

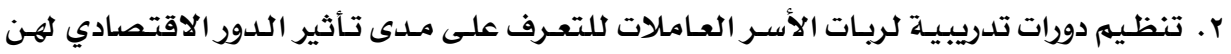

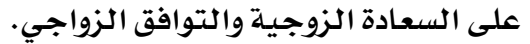

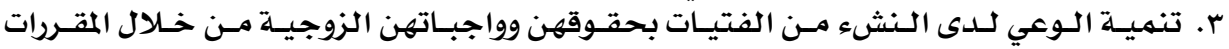

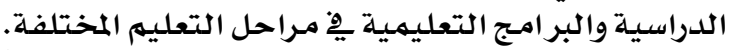

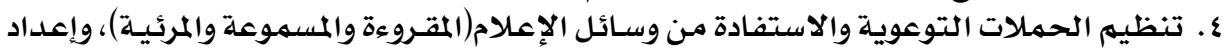

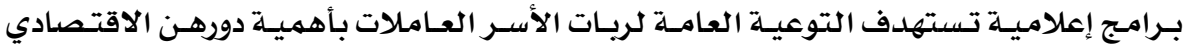

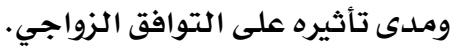




\section{THE ECONOMIGAL ROLE OF THE WORKING SAUDI HOUSEWIFE AND ITS RELATIONSHIP WITH MARITAL COMPATIBILITY}

\section{Enas Bint Ahmad Alssulami}

Research Variables: demographic variables - some socio-economic variables.

Research Statistical methods: Statistical Descriptive toolsfrequencies - percentages - arithmetic average - normative deviation Alpha Cronbach coefficient.

\section{Thesis objectives:}

The research aimed to discover the relationship between economic role of the working housewife and martial compatibility achievement, through distinguishing the relationship between the socio-economic level of the family and dimensions of the economic role of the working housewife and martial compatibility. Also to find the differences between contributed and none contributed housewives on families expenditures and between some socio-economic variables and the dimensions of the martial compatibility.

Research Findings: the research approached to many results but the most important one mentioned that there is a correlation between the total dimensions of the economic role of working housewife and the total dimensions of martial compatibility.

Recommendations: the research recommended that it's necessary to design a guidance program to the young women who are about to get married showing them the importance of the financial income management , and the best ways for dealing with couples. Beside the good ways for achieving martial happiness. And training courses should be organized to the working housewives showing them the influences and defections of their economic role on martial happiness and martial compatibility. 


\section{الدور الاقتصادي لربة الأسرة العاهلة السعودية وعلاتتهه بالتهافق الزواجي}

$$
\text { إعداد }
$$

د ـ إيناس بنت أحمد علي السليميـــ

\section{الاقده همة:}

تتطلسب عمليسة التنميـة والتخطـيط الـشامل تعبئسة كـل المـوارد الماديـة والبـشرية المتاحسـة

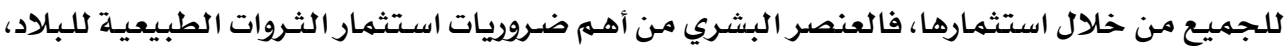

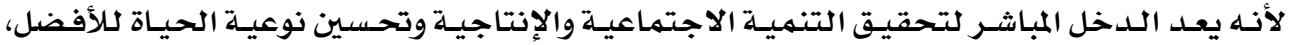

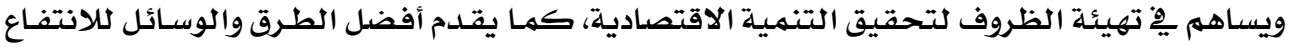

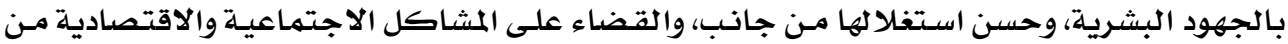
جانب آخر (سليمان، 1991ان ).

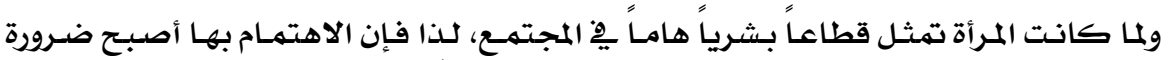

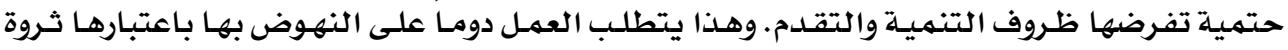

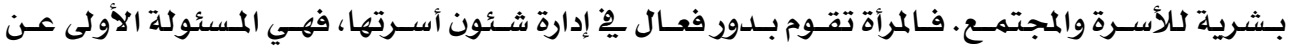

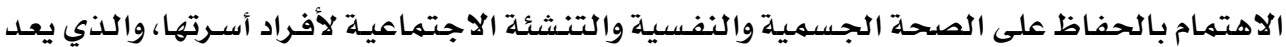
من أهم الأهداف التي تسعى الأسرة لتحقيقها من خلالال سلوكها الإداري(حنا، 1997) .

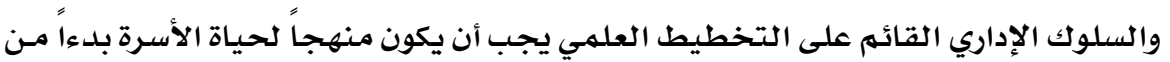

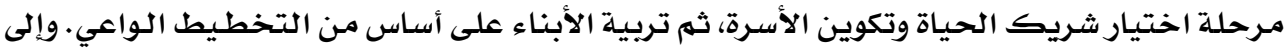

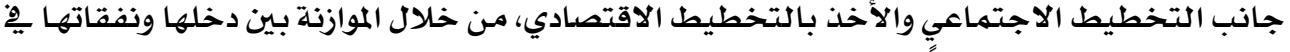

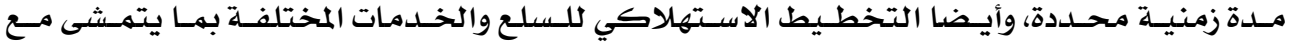

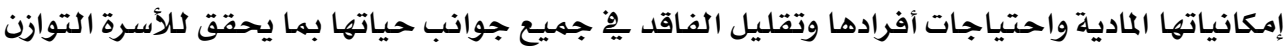

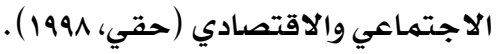

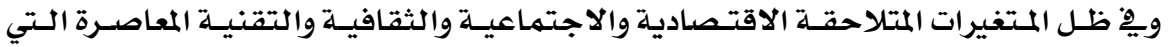

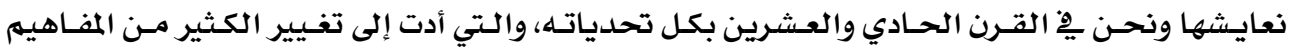

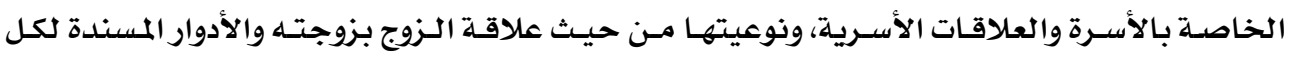

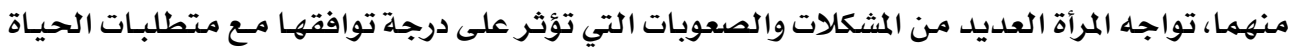

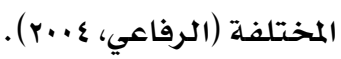

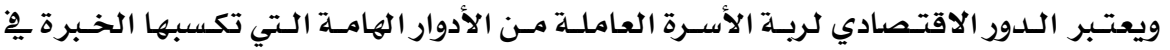

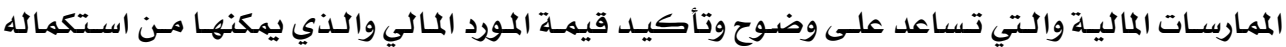


بكفـاءة عاليـة يِّ تغطيـة تكـاليف المعيشة الضـرورية، ومسن ثم يمكنهـا مـن اتخـاذ قـرارات سـليمة فيمـا

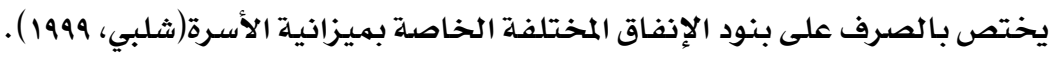
وأشـارت دراسة كل مـن أبو زيــ (1910)، توفيق ( •1991)، حقي وأبـو سكينة (1991) )، أن كثيراً

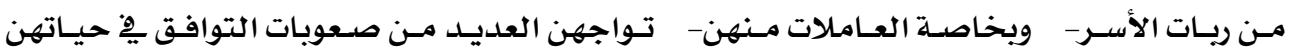

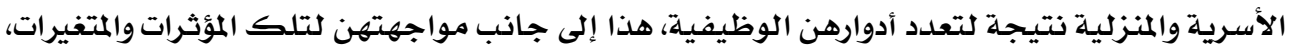

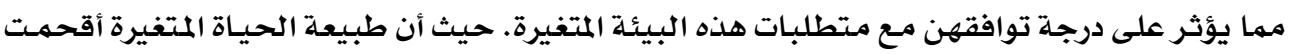

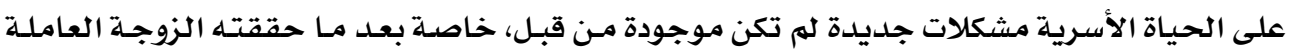

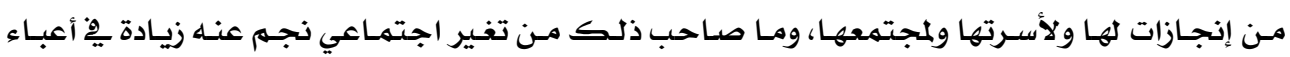

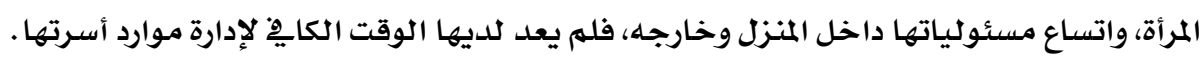

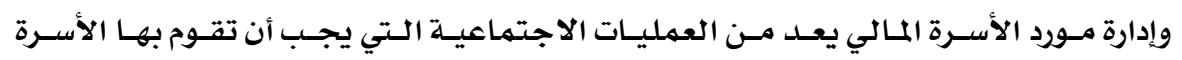

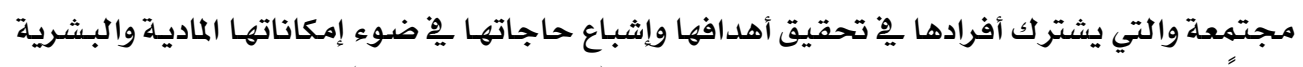

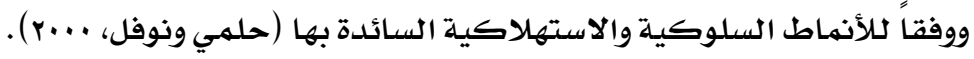

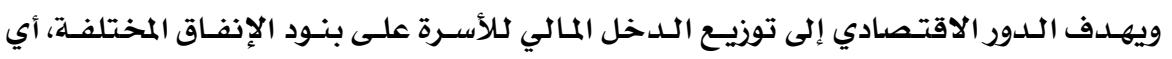

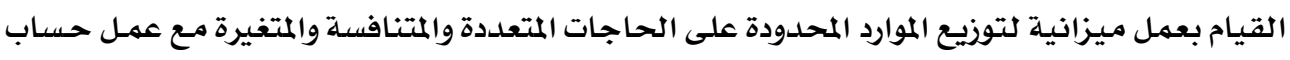

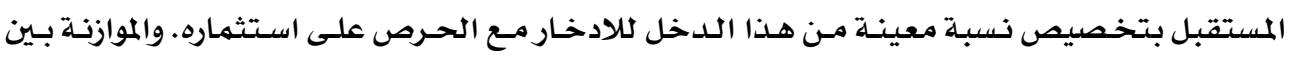

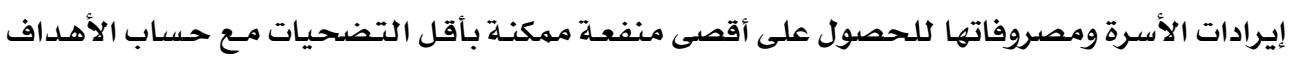
طويلة المدىى (ثلبي، 1999) . وقد ينشأ الاختلاف بين الزوجين بسبب قصور الموارد الاقتصادية عن سـد احتياجـات الأسـرة،

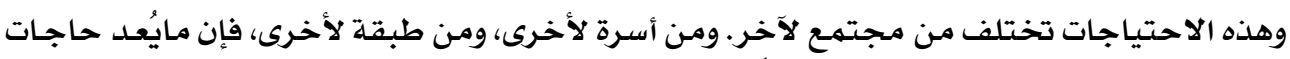

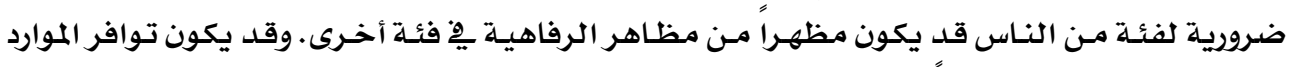

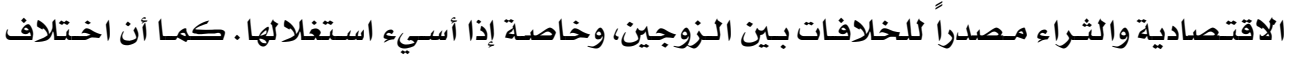

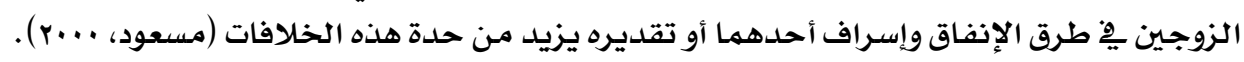

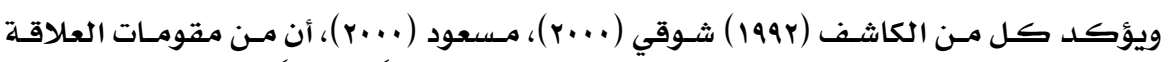

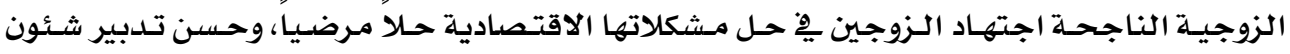

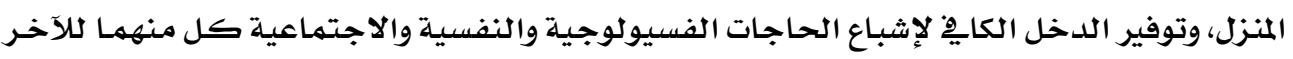

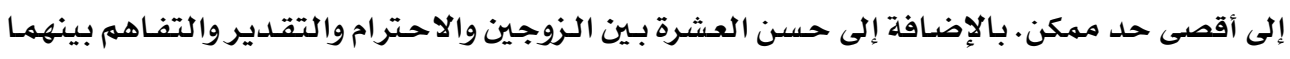

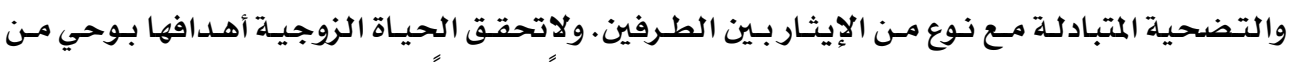

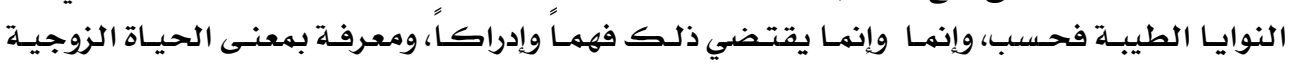

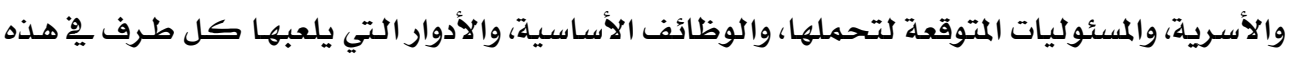
الحياة. كما يعتبر التوافق الزواجي إحدى الركائز التي تمكن الأسرة من أداء وظائفها بكفاءة ومن

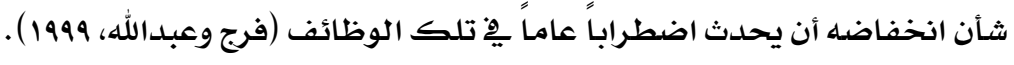


هذا ولقد تبين أن الدراسـات التي تناولت موضـوع التوافق الزواجي لم تتعـرض لتأثير الدـور

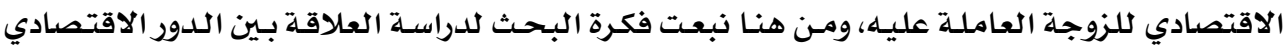

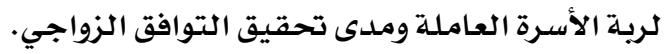

\section{هشكلة البحث وتساويلاته:}

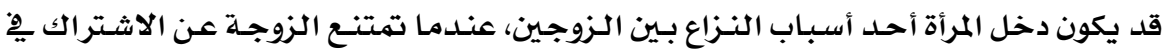

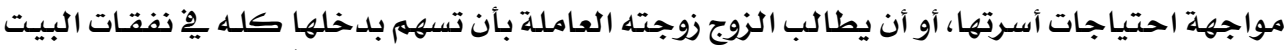

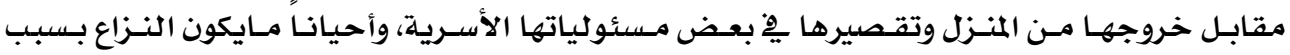

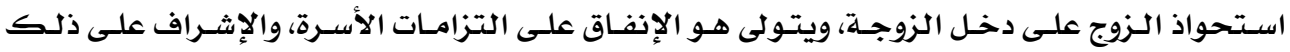

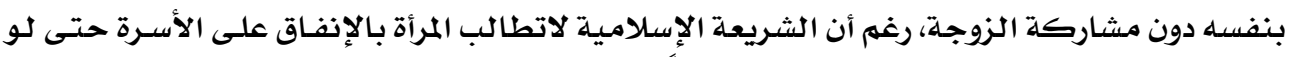

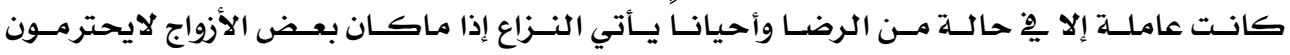

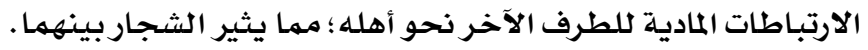

\section{وعلى ضوء ماسبق تتحلدد تساؤلات البحث فيما يلي:}

ا ـ ما مدى العلاقة بـين المتغيرات الاجتهماعيـة والاقتصادية للأسـرة، وأبعـاد الدور الاقتصادي لريسة

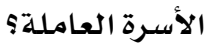

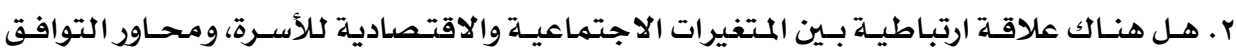

$$
\text { الزواجي؟ }
$$

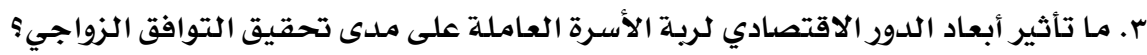

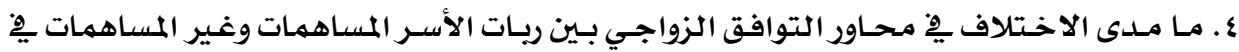

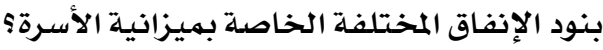

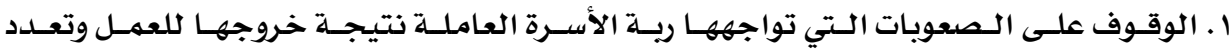

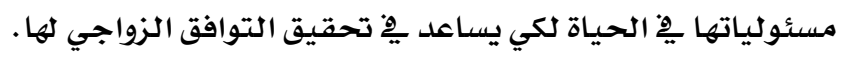

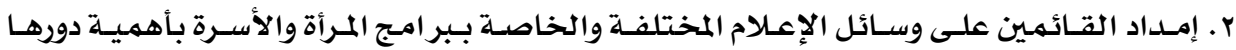

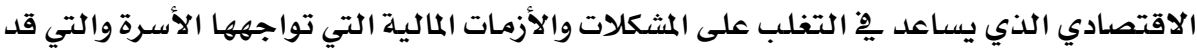

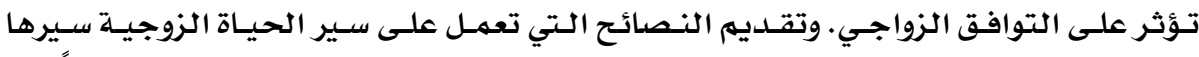

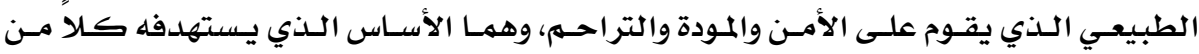
الزوجين يِ حياتهما الأسريـة.

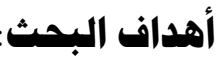

ا ـ إيجـاد العلاقـة بـين المتتفيرات الاجتماعيـة والاقتـصادية للأسـرة وأبعـاد الـدور الاقتصـادي لريـة

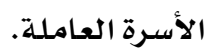

r. الكشف عن العلاقة بين المتغيرات الاجتماعية والاقتصادية للأسرة ومحاور التوافق الزواجي. 
r. معرفة مدى العلاقة الارتباطية بين أبعاد الدور الاقتصادي لربة الأسرة العاملة ومحاور التوافق

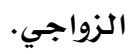

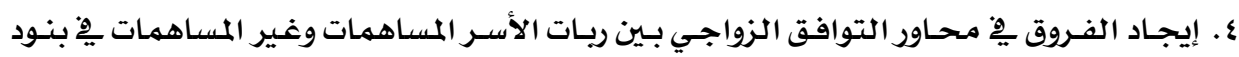

الإنفاق المختلفة، الخاصة بميزانية الأسرة.

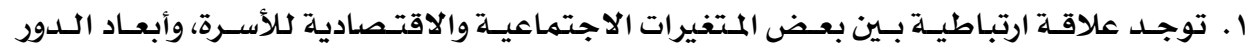

الاقتصادي لريبة الأسرة العاملة.

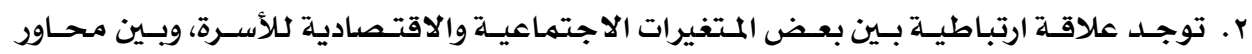

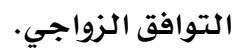

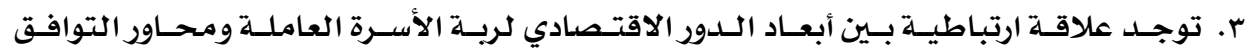

الزواجي. توجي

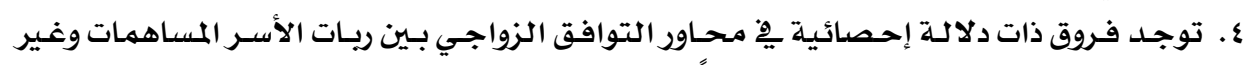

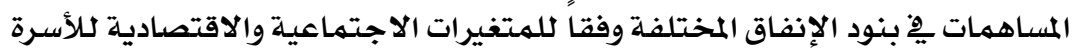

\section{• The Economic Role الدور الاقتصادي :}

تعرفه شـلبي (1999) بأنهـ: " القـرارات التي تتخـــها الأسـرة بشأن تنظيم وتخطيط بنـود

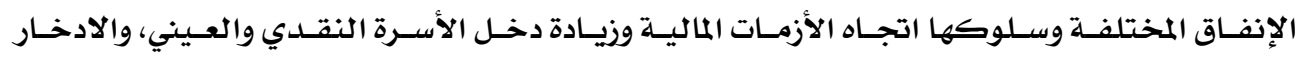

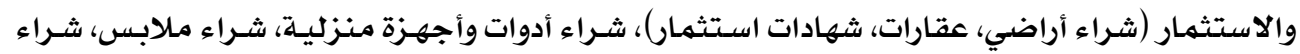

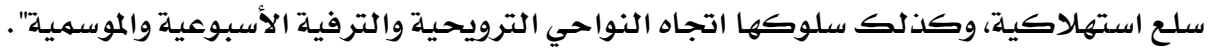

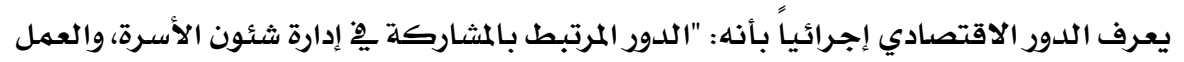

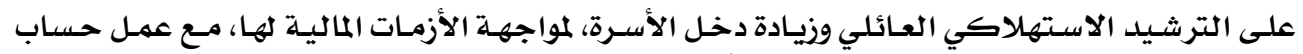

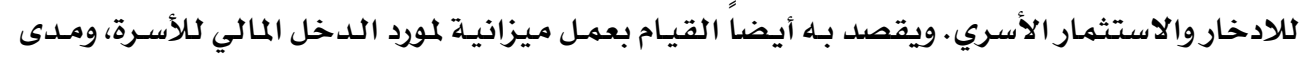

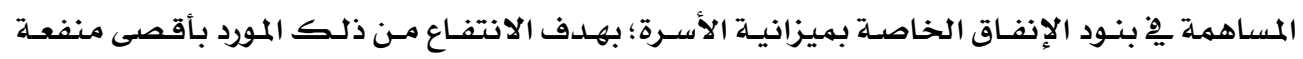

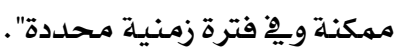

\section{• Marital Compatibility التوافق الزواجي :}

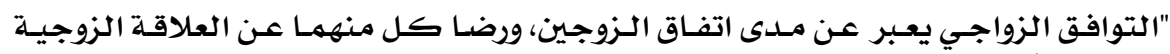

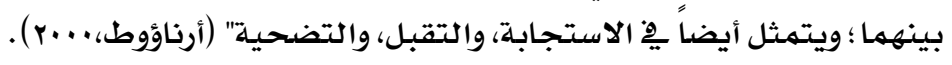

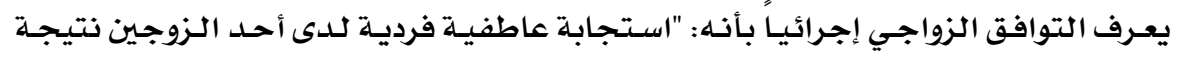

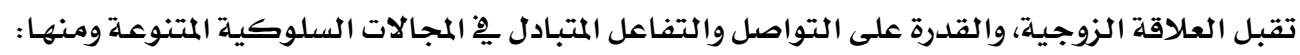

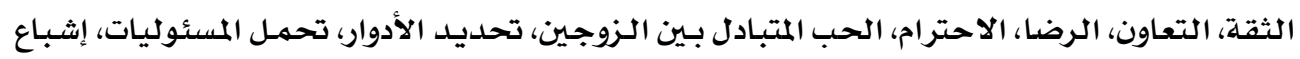




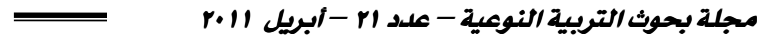

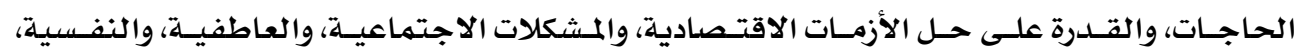
والتربوية، وهو مـايعرف بالسعادة الزوجيـة" .

• • عابة الأسرة العاملة Employee's Housewife

تعـرف ريسة الأسـرة العاملـة إجـرائيـا بـأنهـا الزوجـة الـتي تقــوم بـالعهـل داخـل المنـزل وخـارجـه،

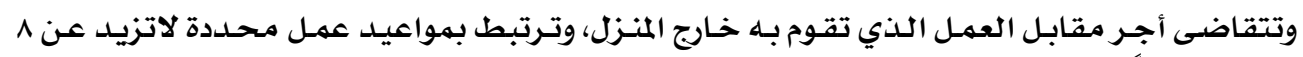

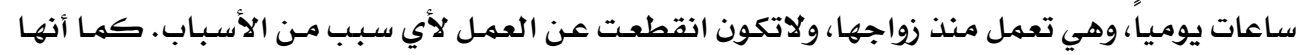
لاتكون قد بدأت منذ فترة قصيرة.

\section{الأسلوب البحثي :}

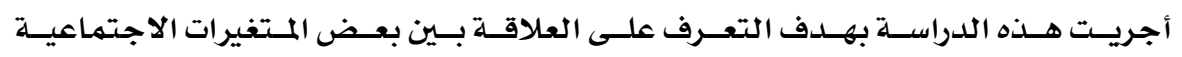

والاقتصسادية وأبعاد الدور الاقتصسادي لربـة الاسـرة العاملـة.والتعـرف علي العلاقـة بـين بعض المتغيرات الاجتمـاعيـة والاقتصـادية للاسـرة ومحساور التوافق الزواجـي. وكذلك ايجـاد العلاقة بـين ابعـاد الدور

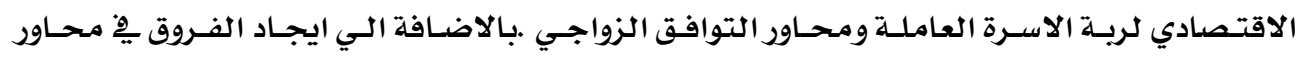

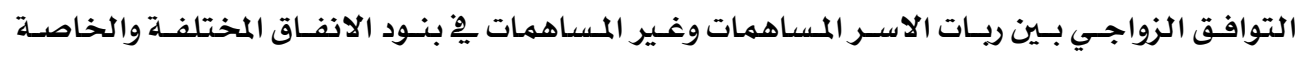

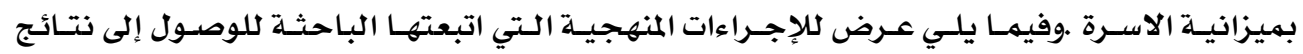

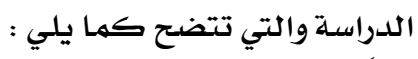

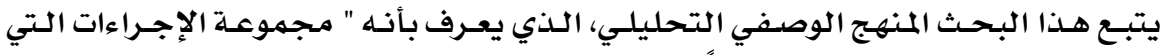

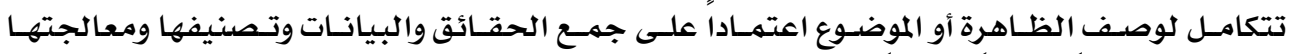

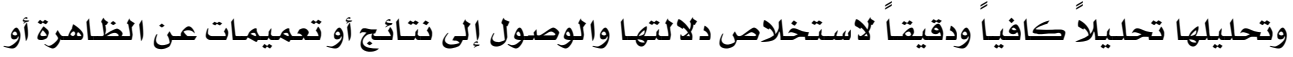

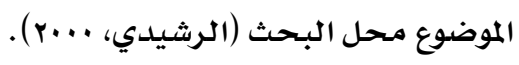
ثانيًا إعداد وبناء أدوات البحث : البحثي، تطلبت هذه الدراسـة إعداد وبناء مجمموعة من الأدوات

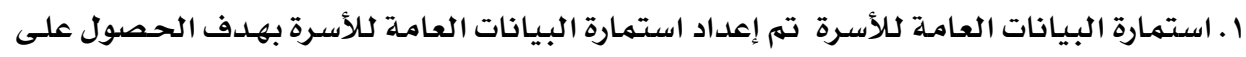

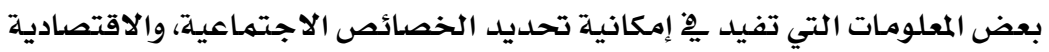
r. استبيان الدور الاقتصادي لرية الأسرة العاملة السعودية (إعداد الباحثة) . وقد تم إعداد استبيان

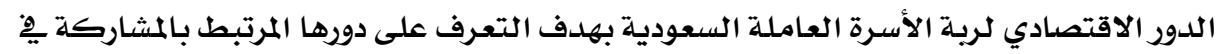

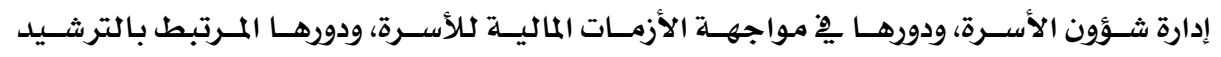

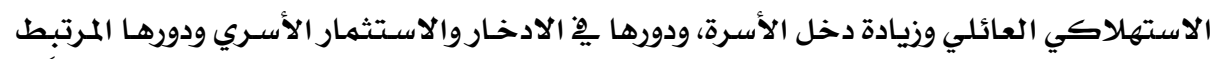

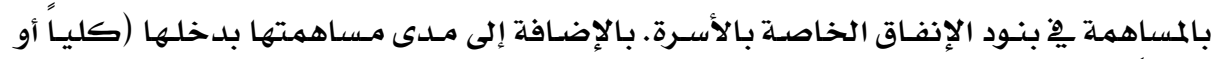

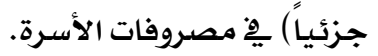




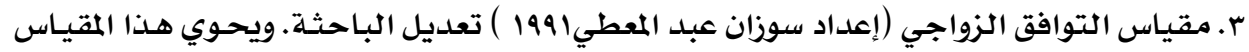

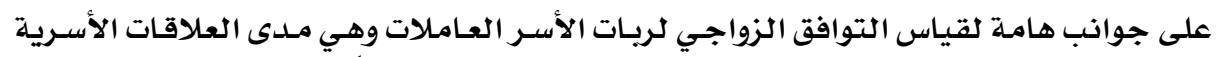

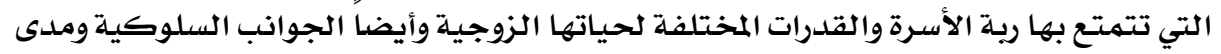

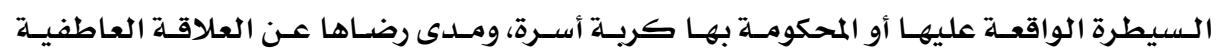

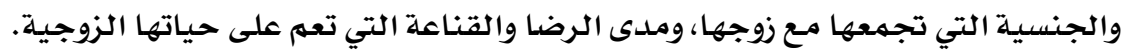

\section{تقنين الأداة : ( يقصد به صدق وثبات الاستبيان)}

ـ صدق الاستبيان.

يقصد به : " قدرة الاستبيان على قياس ماوضع لقياسـه، أو السمـة المراد قياسها، كما يهـدف

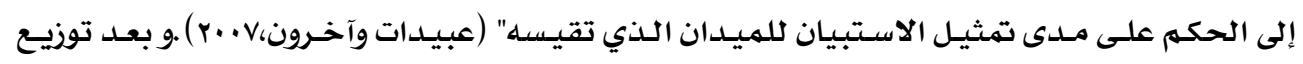

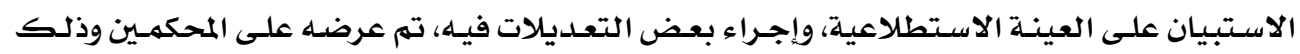

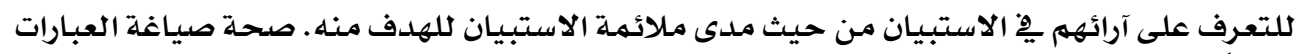

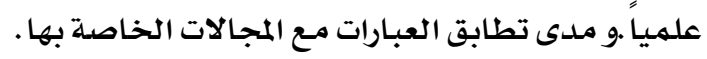

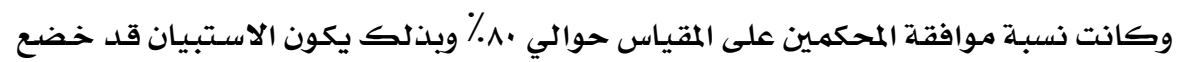
لصدق المحتوى. ـ ت ثبات الاستبييان:

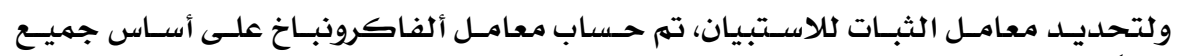

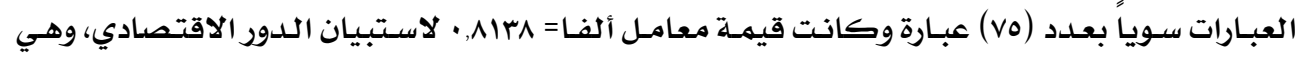

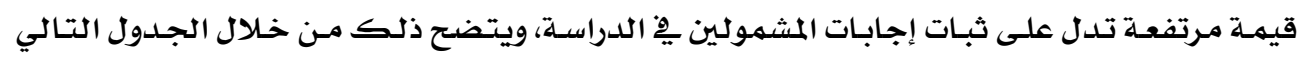

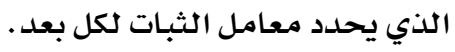

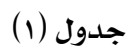

قيم معاملات الثبات لأبعاد استبيان الدور الاقتصادي لربة الأسرة العاملة

\begin{tabular}{|c|c|c|}
\hline 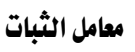 & علد العبارات & 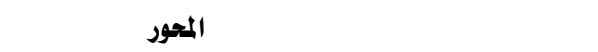 \\
\hline$\cdot$, А 779 & r. & الدور المرتبط بالثشاركة في إدارة شؤون الأسرة \\
\hline - A7ar & $\wedge$ & الدور المرتبط بعواجهة الأزمات المالية للأسرة \\
\hline •, VTEY & ir & اللدور المرتبط بالترشيد الاستهلاكي العائلي وزيادة دخل الأسرة \\
\hline •, VITI & 9 & الدور المرتبط بالادخار والاستثمار الأسري \\
\hline$\cdot, r v \cdot r$ & rq & الدور المرتبط بالمساهمة في بنود الإنفاق الخاصة بالأسرة \\
\hline •,AIrA & vo & الدور الاقتصادي ككل \\
\hline
\end{tabular}


يتضـح من الجدول رقم (1) أن قيم معاملات الاستبيان لأبعـاد الدور الاقتصـادي لربـة الأسـرة

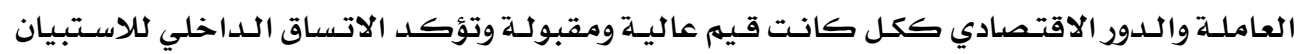
ويمكن تطبيقه.

\section{جـ صدق مقياس التوافق الزواجي.}

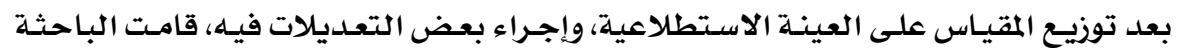

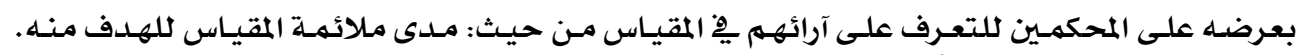

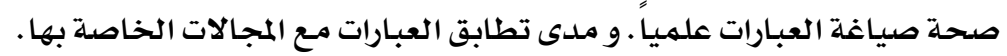

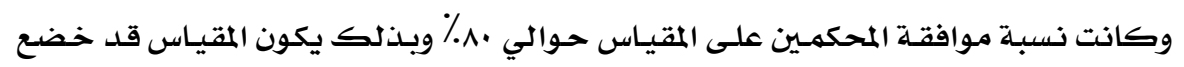

\section{لصدق المحتوى.

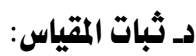

لتحديد معامل الثبات للمقياس، تم حساب معامل ألفاكرونباخ على أساس جميع العبـارات

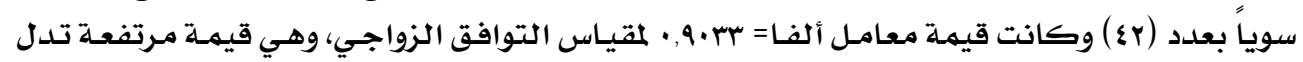

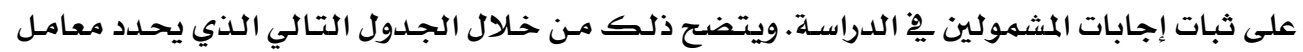
الثبات لمقياس التوافق الزواجي التشولين

جدول (r) (r)

\begin{tabular}{|c|c|c|}
\hline معامل الثبات & عدد العبـارات & الأبعاد \\
\hline$\cdot, 7 \cdot \mu V$ & 1. & العلاقات الأسرية \\
\hline$\cdot 7110$ & 0 & القدرات \\
\hline ع & 0 & الجوانب السلوكية \\
\hline$\cdot, T \leqslant \vee \varepsilon$ & $r$ & السيطرة \\
\hline •, & 9 & الأمور العاطفية والجنسية \\
\hline$\cdot, \Lambda 1 \leqslant \wedge$ & 9 & الرضا الزواجي \\
\hline ( & $\varepsilon r$ & التوافق الزواجي ككل \\
\hline
\end{tabular}

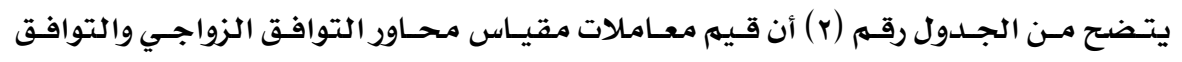

الزواجي ككل كانت قيم عالية ومقبولة وتؤكد الاتساق الداخلي للمقياس ويهكن تطبيقه.

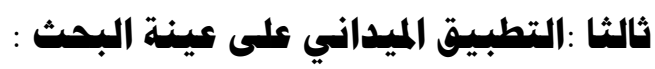

تم تجميع أدوات البحـث يِ شكل استمارة استقصاء واحسدة حتى يسهل توزيعها وتطبيقيها

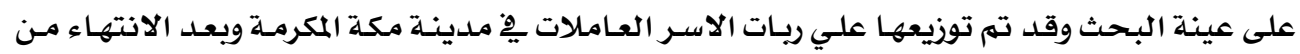


التطبيق الميداني على العينة قامت الباحثة بتصحيح الاستمارات وتحويل الإجابات إلى بيانات رقميـة

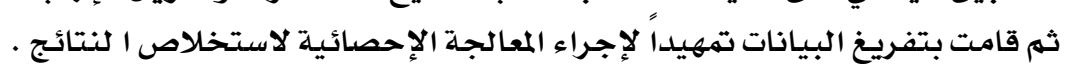

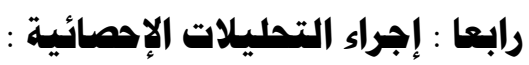

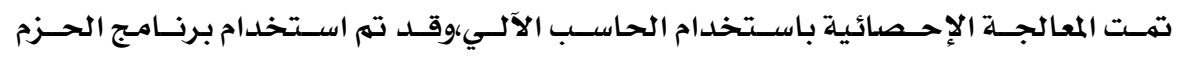
الإحسائية للعلـوم الاجتماعيـة statistical package for social sciences program

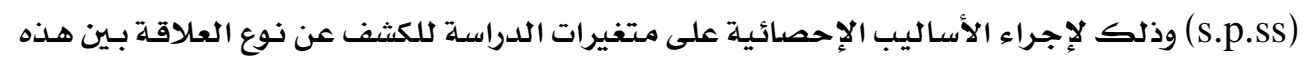

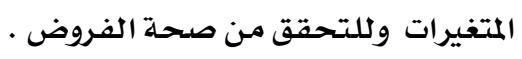

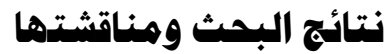

اولا : النتائج الوصفيه

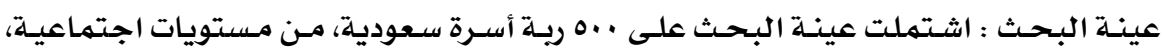

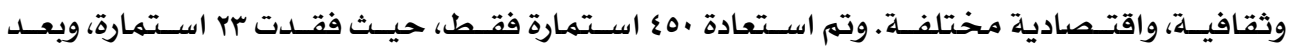

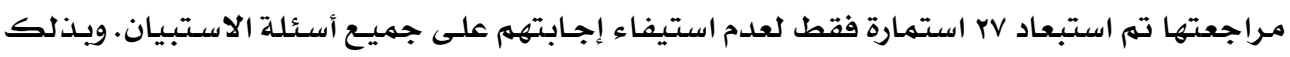

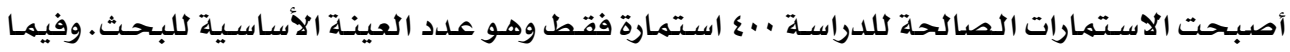

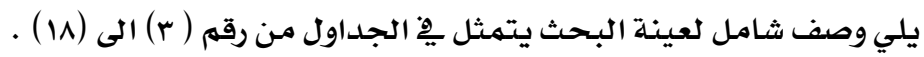

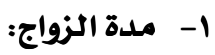
جدول (r)

توزيـع أفراد عينـة البـحث تبعاً لمدة الزواج

\begin{tabular}{|c|c|c|}
\hline النسبـة المئوية & العدد & مدة الزواج \\
\hline$I V, r$ & 79 & أقل من ه سنـوات \\
\hline$I V, \Lambda$ & vi & من ه سنوات لأقل مـن · ا سنوات \\
\hline 19 & VT & من · ا سنوات لأقل مـن 10 سنـة \\
\hline IV,0 & $\mathrm{V} \cdot$ & من 10 سنـة لأقل من ·r سنـة \\
\hline r r n & or & من ·r سنـة لأقل من هب سنـة \\
\hline 9,0 & 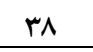 & من هب سنـة لأقل من ·r سنـة \\
\hline $0, \wedge$ & r & 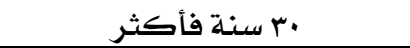 \\
\hline$\% 1 \ldots$ & $\varepsilon \ldots$ & المجمهوع \\
\hline
\end{tabular}

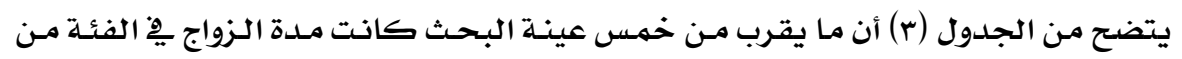

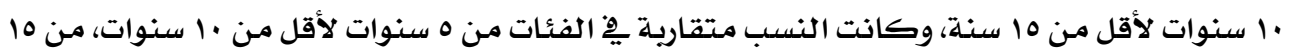

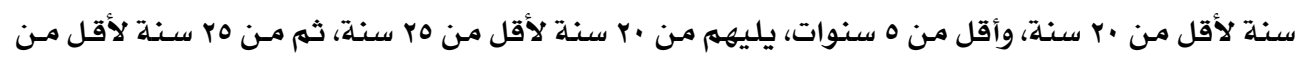

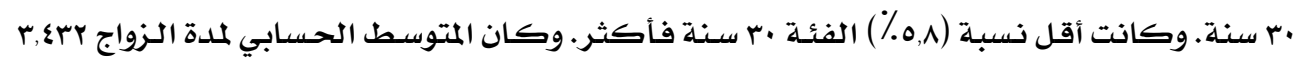




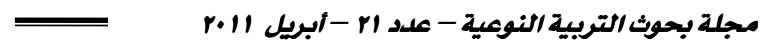

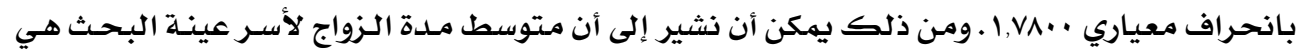

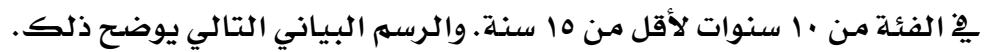

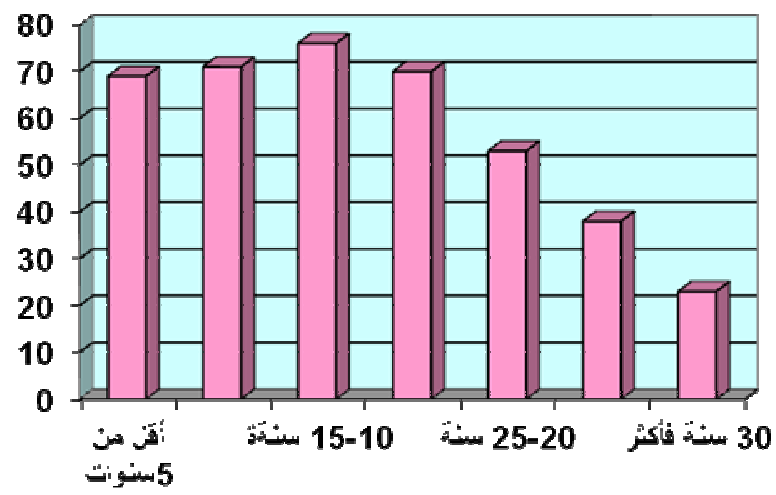

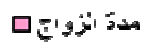

رسهم بياني ( ) يوضح توزيع عينة البحث تبعاً لمدة الزواج

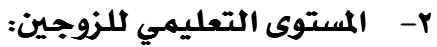

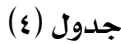

توزيـع أفراد عينـة البحثث تبعا للمستوى التعليمي للزوجين

\begin{tabular}{|c|c|c|c|c|}
\hline \multicolumn{2}{|c|}{ الزوجة } & \multicolumn{2}{|c|}{ 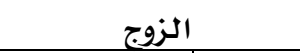 } & \multirow{2}{*}{ المستوى التعليهي للزوجين } \\
\hline النسبـة المئويـة & العدد & النسبـة المئوية & العدد الع & \\
\hline $1, r$ & 0 & $1, \mathrm{~V}$ & V & أمس (لايقرأ ولا يكتب) \\
\hline$\cdot, \mathrm{V}$ & $r$ & 1 & $\varepsilon$ & يقرأ ويكتب \\
\hline 1 & $\varepsilon$ & $\varepsilon$ & 17 & حاصل على الشهادة الابتدائية \\
\hline$\varepsilon, \Lambda$ & 19 & Ir,A & 00 & حاصل على الشهادة المتوسطة \\
\hline Ir,o & ○. & ro & $1 \cdots$ & الثانوية العـامـة ومايعادلها \\
\hline 11 & $\varepsilon \varepsilon$ & 1. r & $\varepsilon 1$ & حاصل على دبلوم \\
\hline rד & ror & 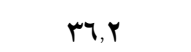 & $1 \leqslant 0$ & حاصل على الشهادة الجـامعيـة \\
\hline$r, \wedge$ & 11 & $\varepsilon, \vee$ & 19 & حاصل على درجـة الماجستير \\
\hline 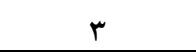 & ir & 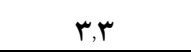 & ir & حاصل على درجـة الدكتوراه \\
\hline$\%$ & $\varepsilon \cdots$ & $\%$ & $\varepsilon \cdots$ & المجموع \\
\hline
\end{tabular}

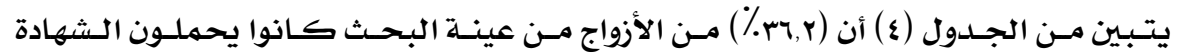

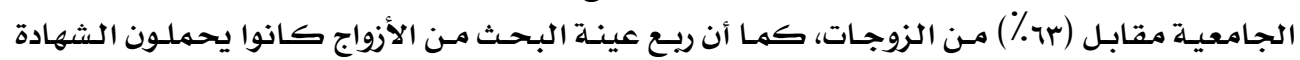




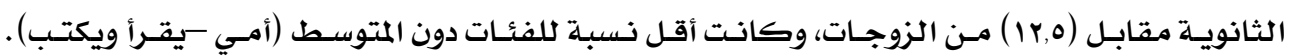

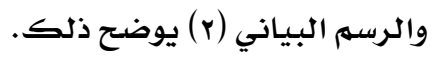
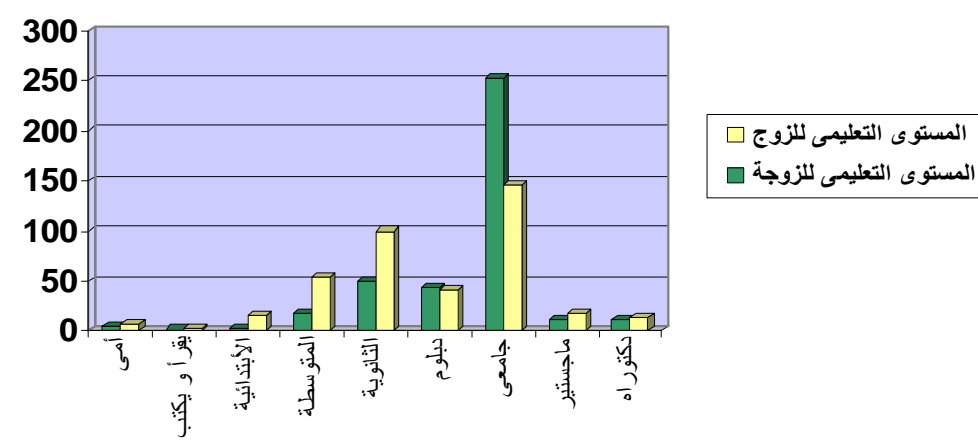

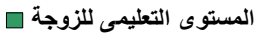

رسم بياني (ץ) يوضح توزيع عينة البحث تبعاً للمستوى التعليمي للزوجين

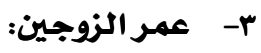

جدول (0)

توزيـع أفراد عينـة البـحث تبعـاً لعمـر الزوجين

\begin{tabular}{|c|c|c|c|c|}
\hline \multicolumn{2}{|c|}{ الزوجة } & \multicolumn{2}{|c|}{ الزوج } & \multirow{2}{*}{ فئة العمر للزوجين } \\
\hline |النسبـة المئوية & العدد ال العد & النسبــة المئويـة & العدد ال العد & \\
\hline $1, V$ & V & $\cdot, \mathrm{V}$ & r & أقل مـن ·r ســـة \\
\hline r & $\Lambda$ & $1 \varepsilon, V$ & 09 & مـن ·r سنـة لأقل مـن ·r سنـة \\
\hline$r \wedge, r$ & 111 & rq,r & $10 \mathrm{~V}$ & من ·r سنـة لأقل مـن ·ع سنـة \\
\hline$\varepsilon 1, r$ & 170 & 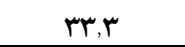 & 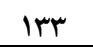 & مـن ·ع سنـة لأقل من ·ه سنـة \\
\hline rz & 97 & 1. & $\varepsilon \cdot$ & من •0 سنـة لأقل من · ج سنـة \\
\hline$Y, \Lambda$ & 11 & r & $\wedge$ & . T سنة فأكثر \\
\hline$\% 1 \ldots$ & $\varepsilon \cdots$ & $\% 1 \ldots$ & $\varepsilon \cdots$ & المجموع \\
\hline
\end{tabular}

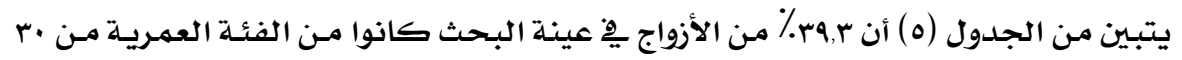

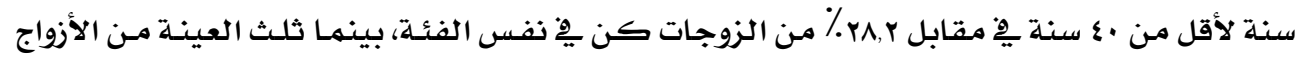

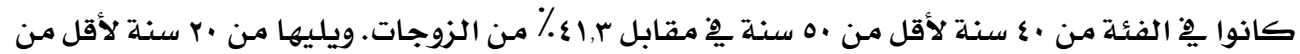

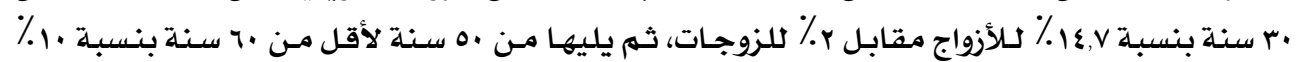

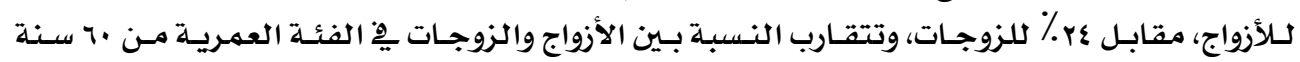

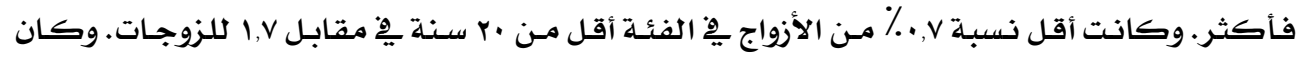

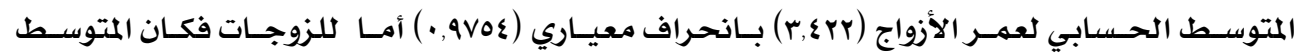




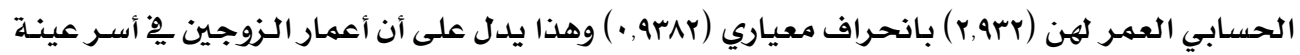

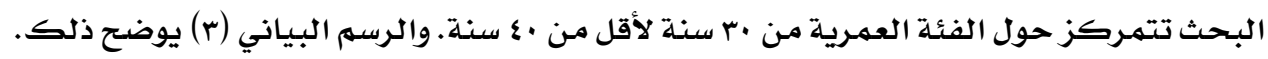

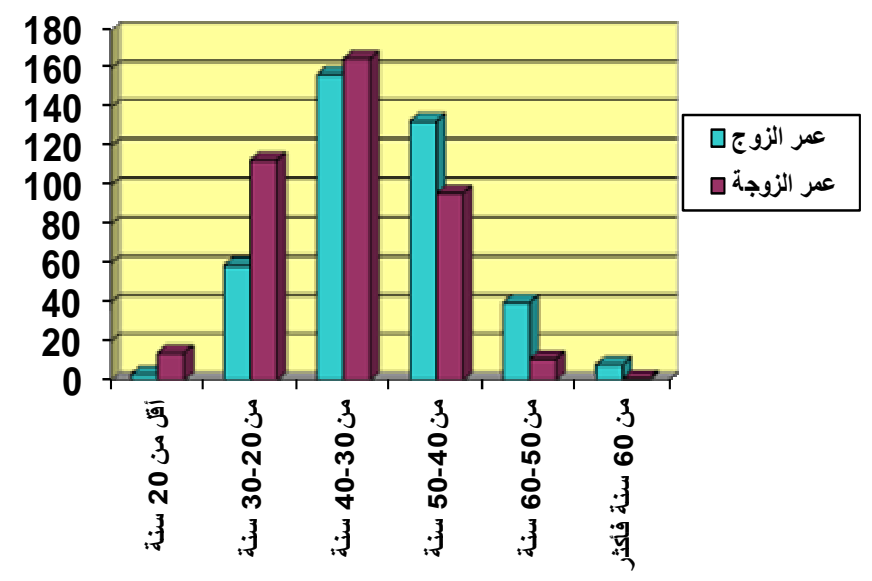

رسم بياني (r) يوضح توزيع عينة البحث تبعاً لعمـر الزوجين

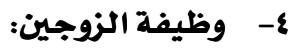

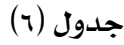

توزيـع أفراد عينـة البحث تبعا لوظيفة الزوجين

\begin{tabular}{|c|c|c|c|c|}
\hline \multicolumn{2}{|c|}{ الزوجة } & \multicolumn{2}{|c|}{ الزوج } & \multirow{2}{*}{ وظيفة الزوجين } \\
\hline النسبـة المئوية & العلدد & النسبــة المئويـة & 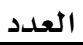 & \\
\hline$\wedge 1, \Lambda$ & rYV & $07, r$ & rro & وظيفة حكومية \\
\hline- & - & Ir,V & 00 & وظيفة حكومية عسكريـة \\
\hline 9,0 & щ & ir,o & $0 \varepsilon$ & وظيفة يِّ قطاع خاص \\
\hline$\varepsilon, 0$ & M & 11 & $\varepsilon \varepsilon$ & أعمال حرة \\
\hline$\varepsilon, Y$ & IV & 0,0 & rr & متقاعد \\
\hline$\% 1 \ldots$ & $\varepsilon \cdots$ & $\% 1 \ldots$ & $\varepsilon \cdots$ & المجموع \\
\hline
\end{tabular}

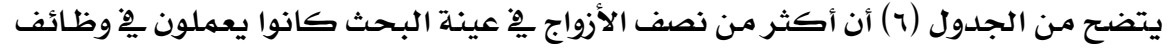

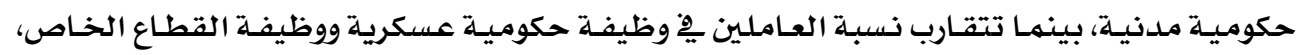

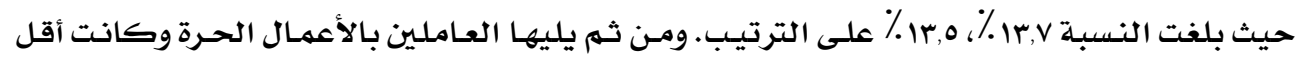

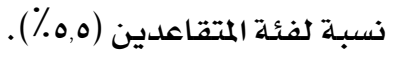




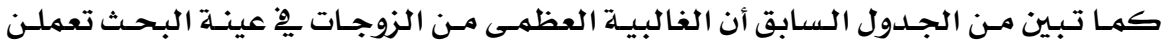

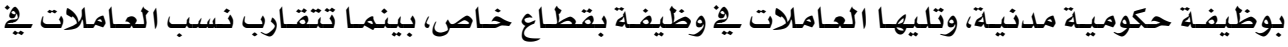

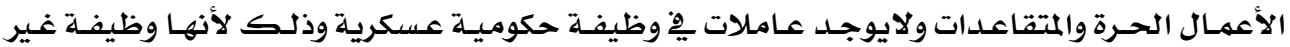
متاحة للسيدات يِّ المجتمـع السعودي. والرسهم البياني (ع) يوضتح ذلك.

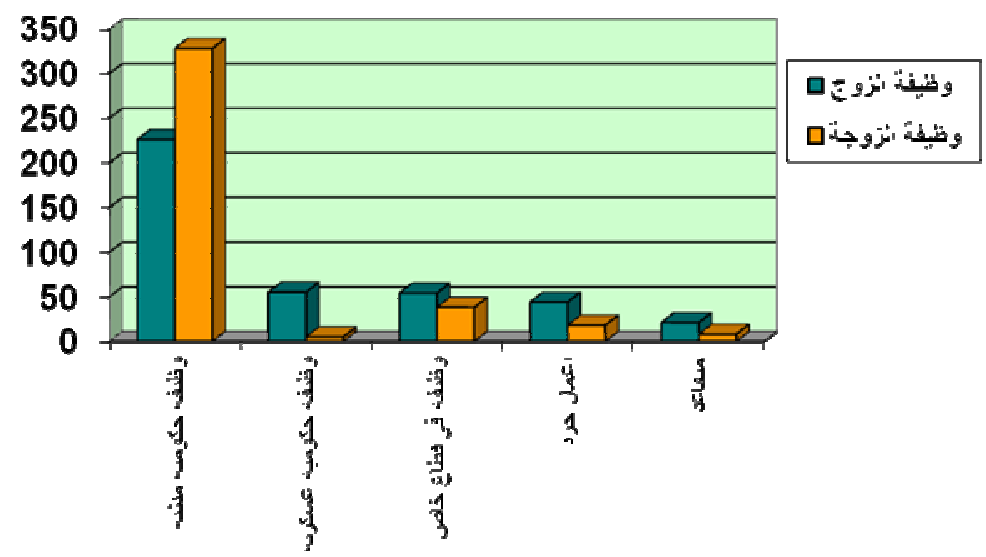

رسم بياني (ع) يوضتح توزيـع عينـة البحث تبعاً لوظيفة الزوجين

ه- عدد أفراد الأسعرة:

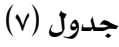

توزيـع أفراد عينة البـحث تبعاً لعدد أفراد الأسرة

\begin{tabular}{|c|c|c|}
\hline النسبية المئويـة & العدد & عدد أفراد الأسـرة \\
\hline$r \cdot, 0$ & IYY & ץ- ع أفراد \\
\hline$\varepsilon \wedge$ & $19 r$ & - - V أفراد \\
\hline 19,0 & V^ & ^- • ا أفراد \\
\hline r & $\wedge$ & أكثر من · ا أفراد \\
\hline$\% 1 \ldots$ & $\varepsilon \cdots$ & المجمهوع \\
\hline
\end{tabular}

يتبين مـن الجـدول (v) أن مـايقرب مـن نصف عينـة البحث كانت عدد أفرادهـا يِّ الفئسة مـن

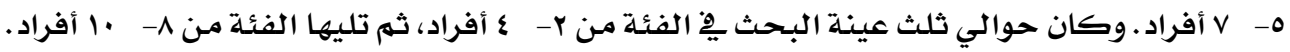

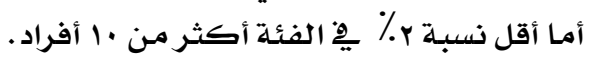




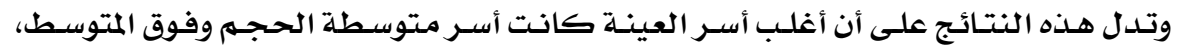

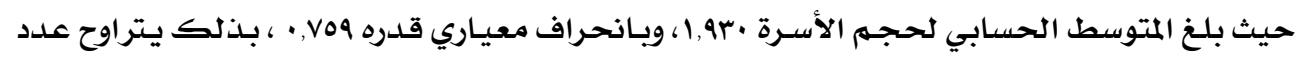

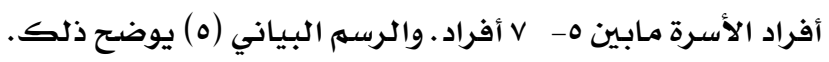

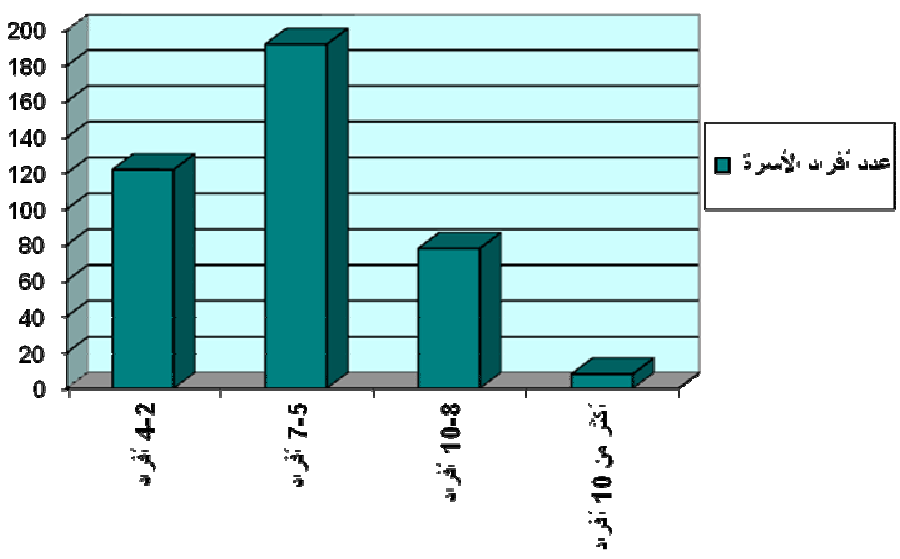

رسم بياني (ه) يوضـح توزيع عينة البحث تبعاً لعدد أفراد الأسرة

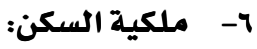

جدول (^)

توزيـع أفراد عينة البحث تبعاً لملكية السكن

\begin{tabular}{|c|c|c|}
\hline النسبـة المئوية & 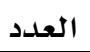 & ملكية السكن \\
\hline$\varepsilon \wedge$ & 194 & ملك \\
\hline$r \varepsilon, 0$ & Ire & إيجار \\
\hline r & $\wedge$ & منزل تابع لجهة العمل \\
\hline 10,0 & Tr & ملك للعائلة \\
\hline$\% 1 \ldots$ & $\varepsilon \cdots$ & المجموع \\
\hline
\end{tabular}

يتبين من الجدول (^) أن مـايقرب مـن نصف عينـة البحثث تمتلـك المسكن الذي تعيث فيـه،

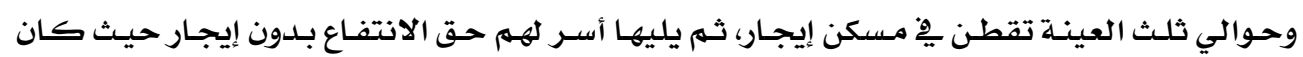

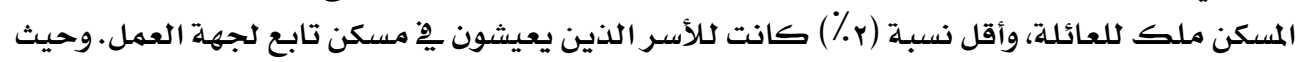

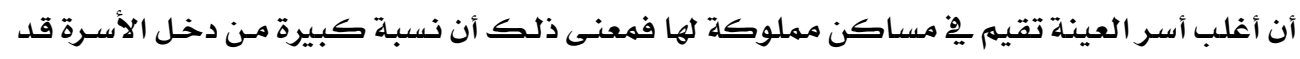

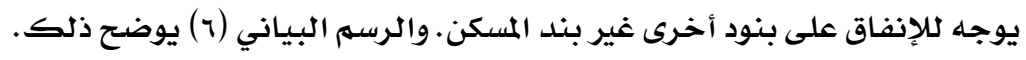




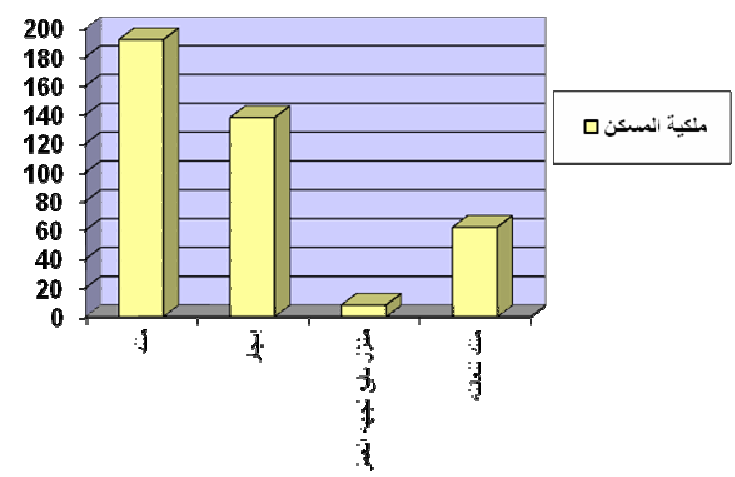

رسم بياني ( ) يوضح توزيع عينة البحث تبعاً لملكية السكن

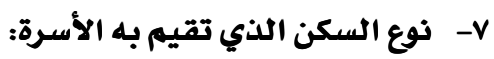

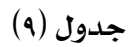

توزيـع أفراد عينـة البحث تبعاً لنوع المسكن

\begin{tabular}{|c|c|c|}
\hline النسبــة المئويـة & العدد & نوع المسكن \\
\hline$\cdot, \mathrm{V}$ & $r$ & سـكن شعبي \\
\hline $1 \cdot r$ & $\varepsilon 1$ & شقة (1- ب غرف) \\
\hline$\varepsilon 9$ & 197 & شقة (ع غرف فأكثر) \\
\hline$\varepsilon$. & 17. & فيلا \\
\hline$\%$ & $\varepsilon \cdots$ & المجهوع \\
\hline
\end{tabular}

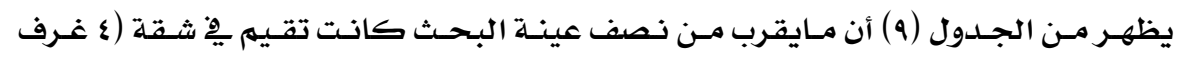

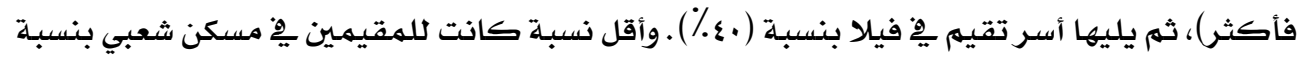

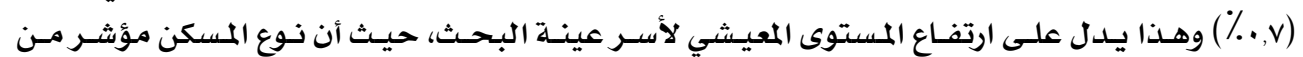

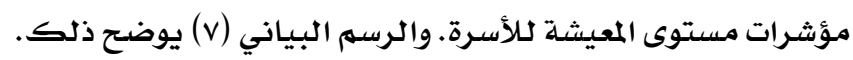

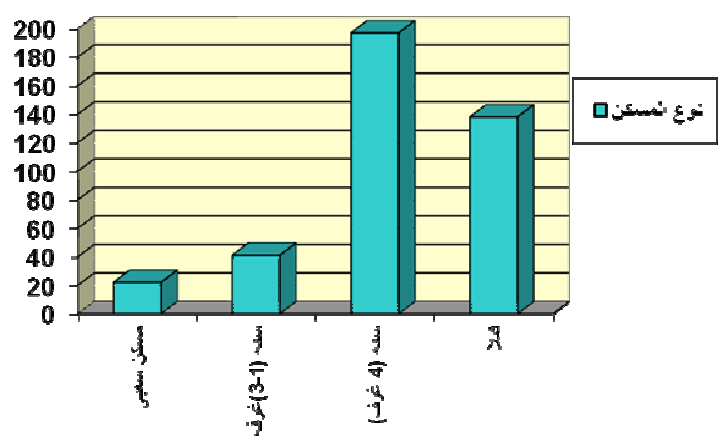

رسهم بياني (v) يوضـح توزيـع عينة البحث تبعـاً لنوع المسكن 


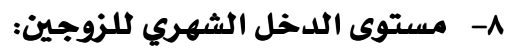

جدول (1.)

توزيـع أفراد عينـة البحث تبعاً لمستويـات الدخل الشهري للزوجين

\begin{tabular}{|c|c|c|c|c|}
\hline \multicolumn{2}{|c|}{ الزوجة } & \multicolumn{2}{|l|}{ الزوج } & \multirow{2}{*}{ مقدار الدخل الشهري للزوجين } \\
\hline | النسبـة المئويـة| & العدد - العد & النسبـة المئويـة & العدد & \\
\hline $1 \varepsilon, r$ & ov & ir & $\varepsilon \wedge$ & أقل من ....ب ريال \\
\hline $10, \mathrm{~V}$ & זד & $I V, r$ & 79 & 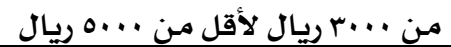 \\
\hline $1 \wedge, V$ & vo & $19, Y$ & VV & من · . .0 ريال لأقل من ... ريال \\
\hline rl, r & ^० & $19, \mathrm{~V}$ & va & 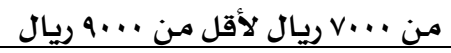 \\
\hline 10 & 7. & $1 \varepsilon$ & 07 & من · . .9 ريـال لأقل من · . . 11 ريـال \\
\hline 10 & 7. & $I V, \Lambda$ & vi & أكثر من · .. ․ \\
\hline$\% 1 \ldots$ & $\varepsilon \cdots$ & $\% 1 \ldots$ & $\varepsilon \cdots$ & المجموع \\
\hline
\end{tabular}

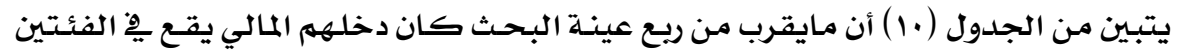

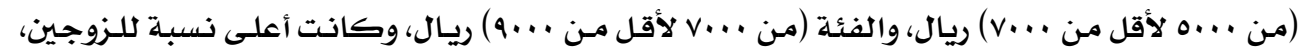

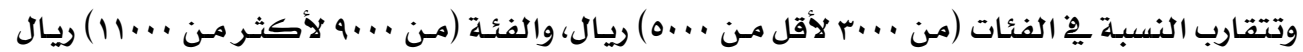

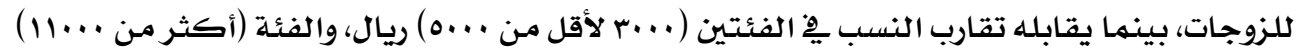

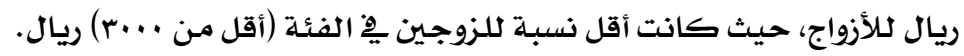

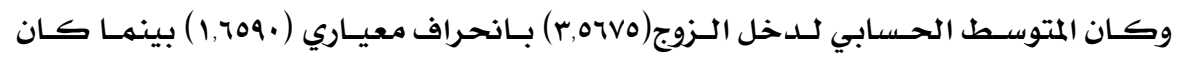

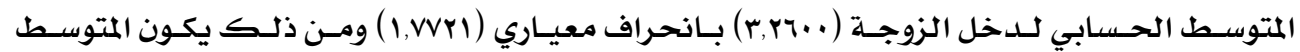

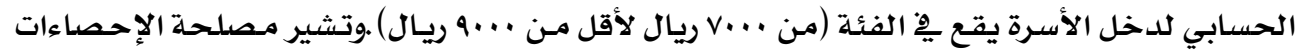

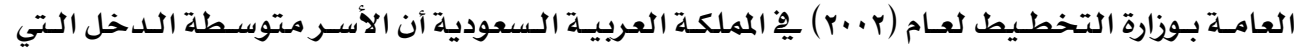

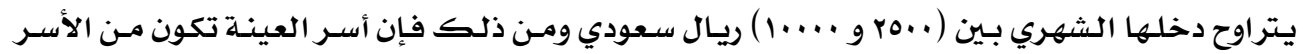

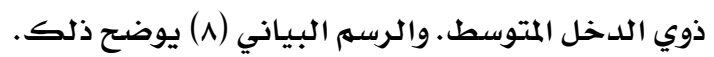

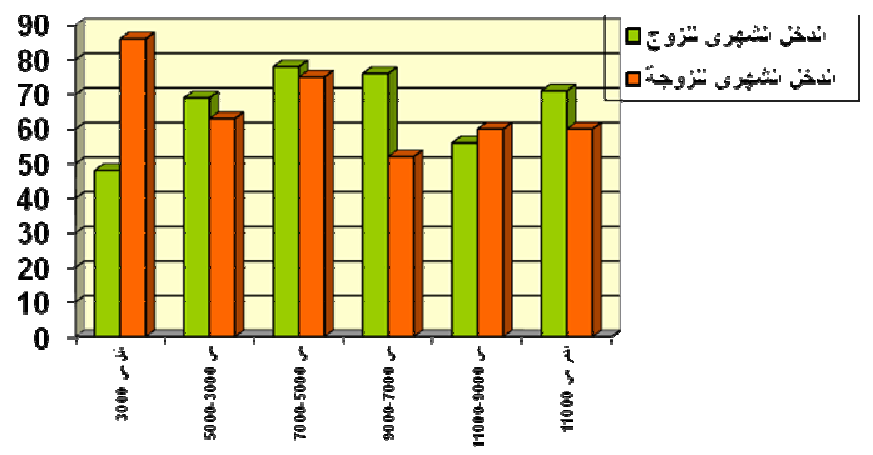

رسهم بياني (^) يوضـح توزيـع عينـة البحث تبعاً للدخل الشهري للزوج والزوجة 
جدول (II)

توزيـع أفراد عينـة البـحث تبعاً للهصادر الإضـافية لزيـادة دخل الأسـرة

\begin{tabular}{|c|c|c|}
\hline النسبية المئويـة & العدد الع & المصسادر الإضـافيـة لزيادة دخل الأسـرة \\
\hline ro & $1 \cdots$ & نعم \\
\hline vo & r... & 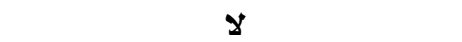 \\
\hline$\% 1 \ldots$ & $\varepsilon \cdots$ & المجهموع \\
\hline
\end{tabular}

يوضـح الجدول (11) أن ثلاث أرياع عينة البحث ليس لها مصادر إضافية لزيـادة دخل الأسـرة.

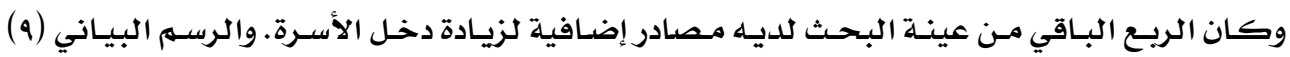

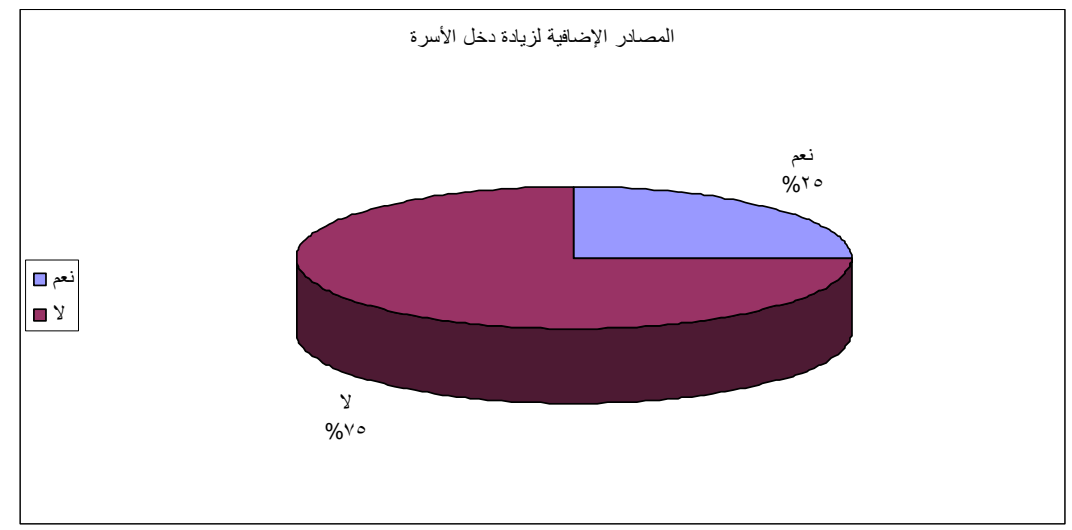

رسهم بياني (ه) يوضح توزيع عينة البحث تبعاً للمصادر الإضافية لزيادة دخل الأسرة

• 1- مساهمة ريات الأسر العاملات ِِّ بنود الإنفاق الخاصة بميزانية الأسرة:

جدول (ir)

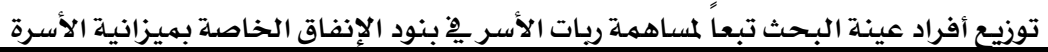

\begin{tabular}{|c|c|c|}
\hline النسبة المئوية & 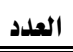 & مساهمة ربات الأسر العاملات في بنود الإنفاق الخاصة بيزانية الأسرة \\
\hline$r v, r$ & 101 & أساهم بلدخلي كاملاً \\
\hline 09,0 & rrA & أساهم أحياثاً \\
\hline$r, \Lambda$ & 11 & لا أساهم \\
\hline$\%$ & \&.. & المجهوع \\
\hline
\end{tabular}

يتضح من الجدول ( r ) أن أكثر من نصف ريات أسر عينـة البحث تساهم أحياناً ِِِ عمليـة

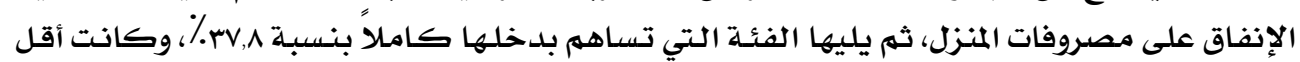




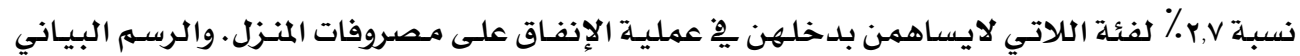
. (1.)

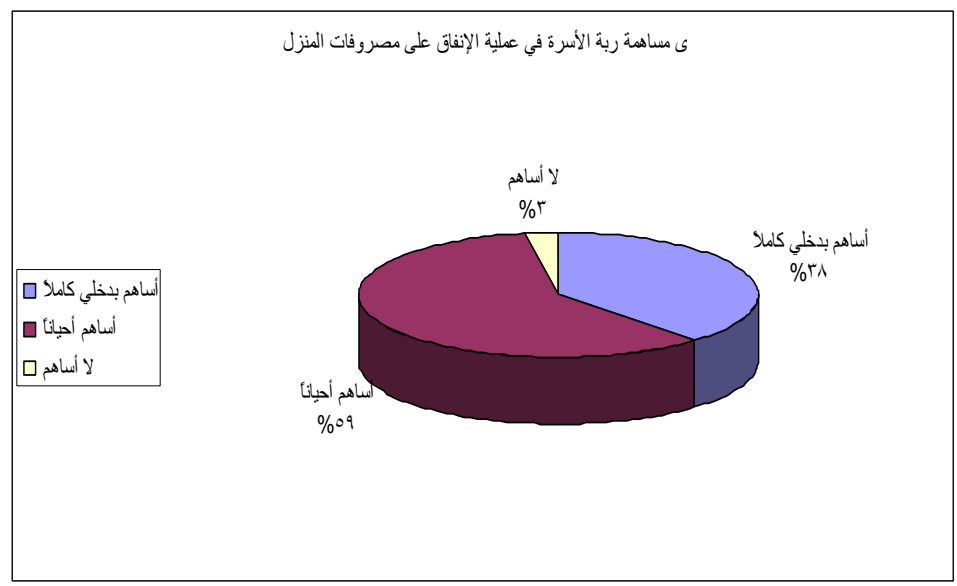

رسهم بياني ( • 1) يوضـح توزيـع عينـة البحث تبعاً لمسـاهمة ريات الأسـر ِِ بنود الإنفاق الخاصدة بميزانية الأسـرة ا- معدل مساهمة ريات الأسبر العاملات بِ بنود الإنفاق الخاصة بميزانية الأسرة:

جدول (ir)

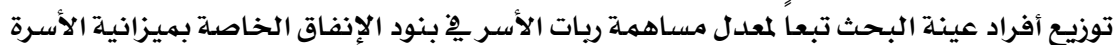

\begin{tabular}{|c|c|c|}
\hline النسبة المئوية & 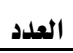 & معدل مساهمة ربات الأسر العاملات في بنود الإنقاق الخاصة بميزانية الأسرة \\
\hline 11 & $\varepsilon r$ & أساهم بما يعادل الربع \\
\hline 9 & ro & أساهم بما يعادل الثلث \\
\hline rr & 10 & أساهم بما يعادل النصف \\
\hline re & Vy & أساهم بما يعادل الثلاث أرباع \\
\hline ra & 101 & أساهم بكامل الدخل \\
\hline$\%$ & rAq & المجموع \\
\hline
\end{tabular}

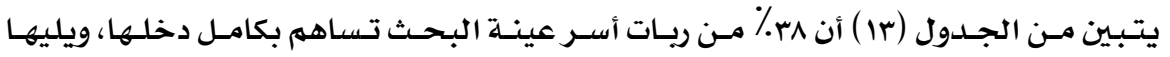

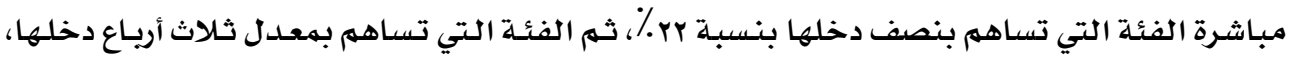

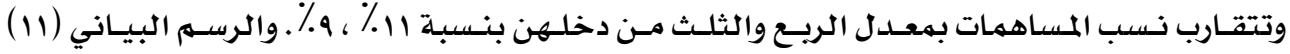
يوضح ذلك. 
معدل مساهمة ربات الأسر العاهلات في بنود الإنفاق الخاصة بميزانية الأسرة

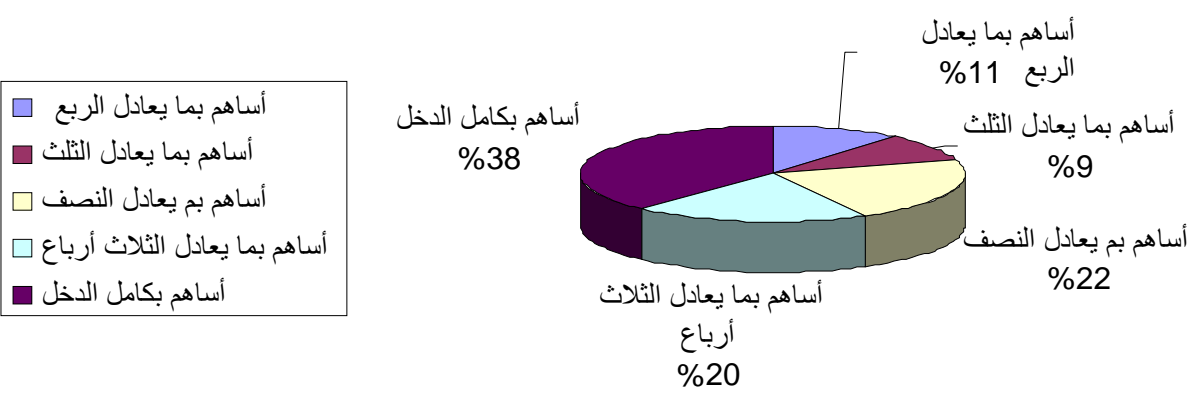

رسم بياني (11) يوضح توزيع عينة البحث تبعاً لمعدل مساهمة ريات الأسر العاملات بِّ بنود الإنفاق الخاصدة بميزانية الأسرة

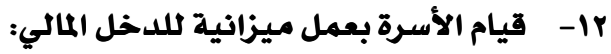

جدول (is)

توزيـع أفراد عينـة البحث تبعـا للقيام بعمل ميزانية للدخل المالي للأسـرة

\begin{tabular}{|c|c|c|}
\hline النسبة المئوية & 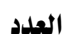 & قيام الأسرة بعمل ميزانية للدخل المالي \\
\hline ro,r & 1.1 & دائماً \\
\hline 01,0 & $r+q$ & أحياثاً \\
\hline$r r, r$ & 94 & y \\
\hline$\% 1$. & 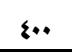 & المجموع \\
\hline
\end{tabular}

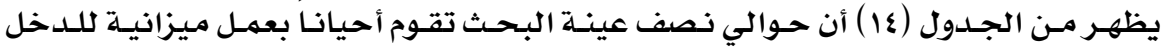

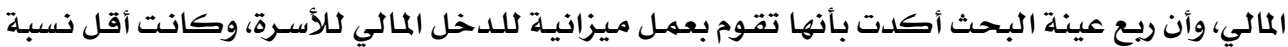

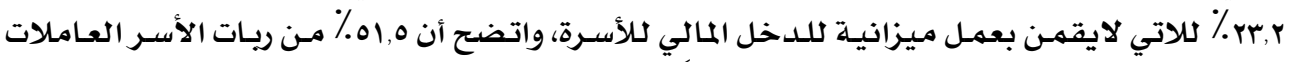

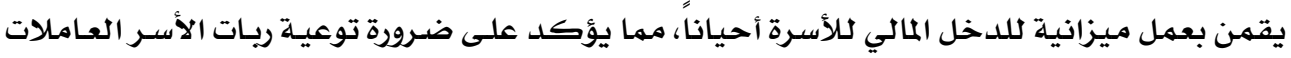

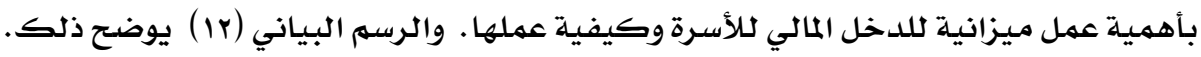




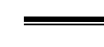

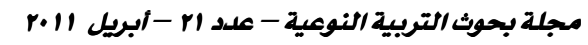

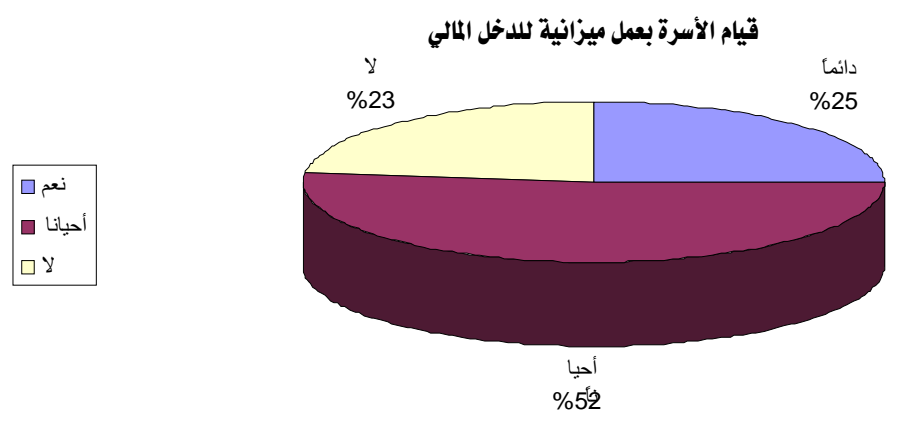

رسم بياني ( r ) يوضح توزيع عينة البحث تبعاً للقيام بعمل ميزانية للدخل المالي للأسرة

rا- أفراد الأسرة الذين يشاركون بعمل ميزانية الدخل للأسرة:

جدول (10)

توزيـع أفراد عينة البحث تبعاً لأفراد الأسرة الذين يشاركون بعمل ميزانية الدخل للأسرة

\begin{tabular}{|c|c|c|}
\hline النسبـة المئويـة & 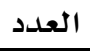 & الذي يقوم بعمل الميزانية \\
\hline 7,0 & $r \cdot$ & الزوج فقط \\
\hline$I V, r$ & or & الزوجة فقط \\
\hline$V Y, r$ & rrr & الزوج والزوجـة معاً \\
\hline$r, 9$ & ir & الزوج والزوجـة مـع الأبناء \\
\hline$\% 1 \ldots$ & $r \cdot v$ & المجموع \\
\hline
\end{tabular}

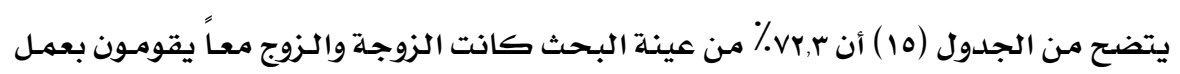

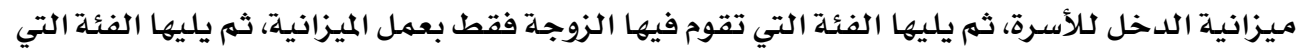

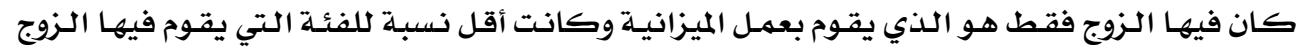

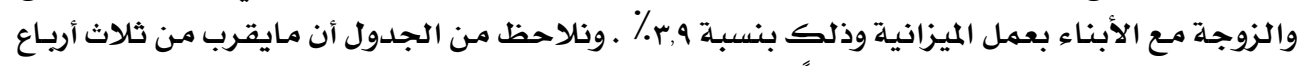

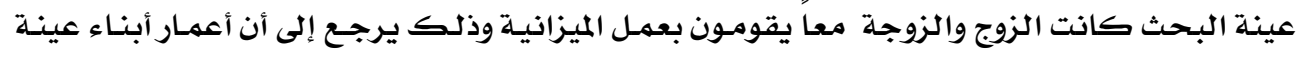

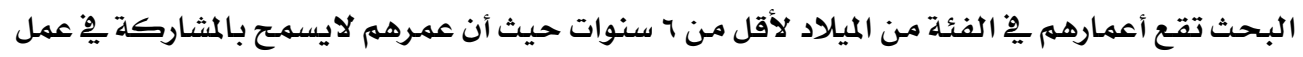

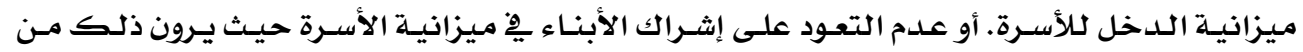

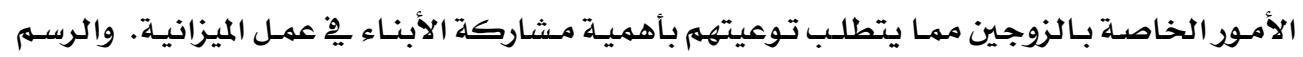
البياني (rا) يوضح ذلك. 
أفراد الأسرة الذين يشاركون بعمل ميزانية دخل الأسرة

الزوج فقط

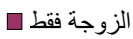

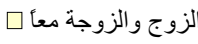

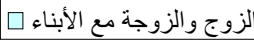

الزوج فقط الزوج والزوجة مع الأبناء

\%3,9 \%6,5

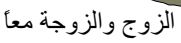

\%72,3

رسهم بياني (با ) يوضـح توزيـع عينـة البـحث تبعاً لأفراد الأسـرة الذين يشاركون بعمل ميزانية الدخل لكلأسرة

ع ا- نوع الميزانية التي تقوم الأسرة بوضعها:

جدول (17)

توزيـع أفراد عينـة البحث تبعاً لنوع الميزانية التي تقوم الأسـرة بوضعها

\begin{tabular}{|c|c|c|}
\hline النسبـة المئويـة & 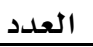 & نوع الميزانية التي تقوم الأسـرة بوضعها \\
\hline Y乏 & vo & ميززانيـة مكتوبـة \\
\hline V7 & rrr & ميزانيـة ذهنيـة \\
\hline$\% 1 \ldots$ & $r \cdot v$ & المجهوع \\
\hline
\end{tabular}

يتضـح من الجدول (17) أن مايقرب من ثلاث أرباع عينـة البحث تعتمهد على الميزانية الذهنيـة

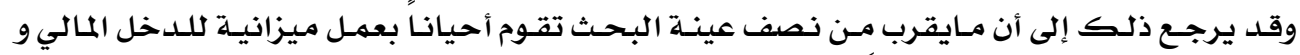

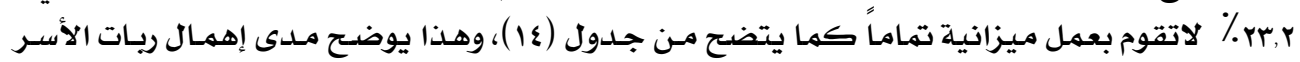

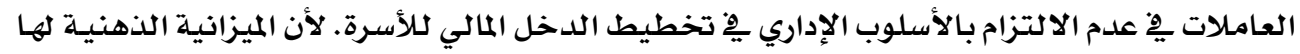

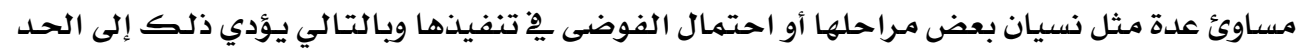
من القدرة على تحسـين الأسلوب الإداري، وكان الربع المتبقي مـن عينــة البـحث يقومـون بعهـل ميزانيـة

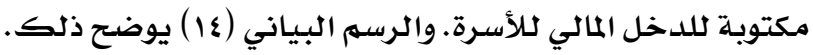

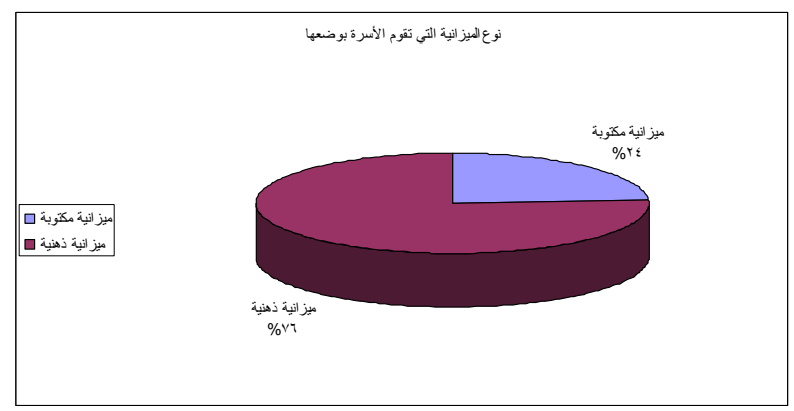

رسهم بياني (ع ا ) يوضح توزيع عينة البحث تبعاً لنوع الميزانية التي تقوم الأسـرة بوضعها 
10- أنواع الميزانيات التي تقوم الأسرة بوضعها:

جدول (iv)

توزيـع أفراد عينـة البـحث تبعاً لنوع الميزانية التي تقوم الأسـرة بوضعها مـن حيث المدى الزمـني

\begin{tabular}{|c|c|c|}
\hline النسبـة المئويـة & 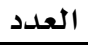 & نوع الميزانيـة التي تقوم الأسـرة بوضعها مـن حيث المدى الزمـني \\
\hline$\varepsilon$ & ir & ميزانيـة يوميـة \\
\hline 9. & rvo & ميززانية شهرية \\
\hline 7 & r. & ميزانيـة سنويـة \\
\hline$\% 1 \ldots$ & $r \cdot v$ & المجهوع \\
\hline
\end{tabular}

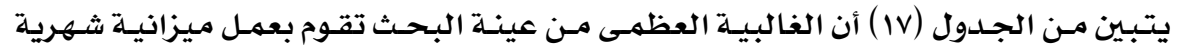

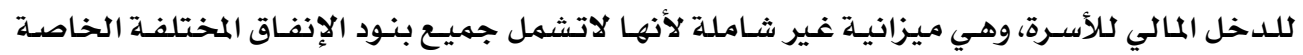

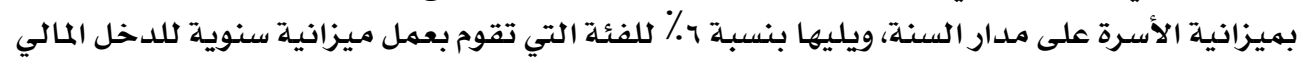

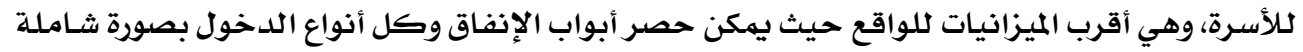

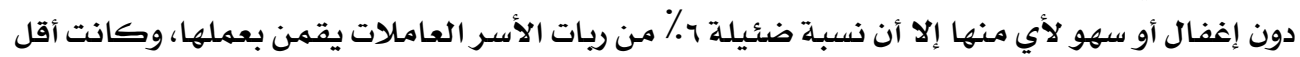

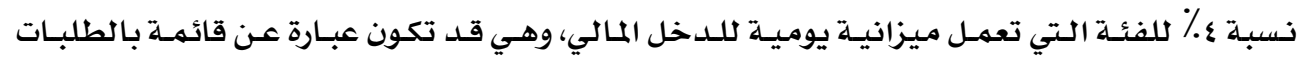

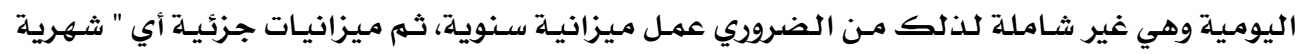

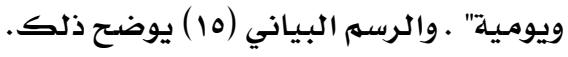

نوع الميزانية التي تقوم الأسرة بوضعها

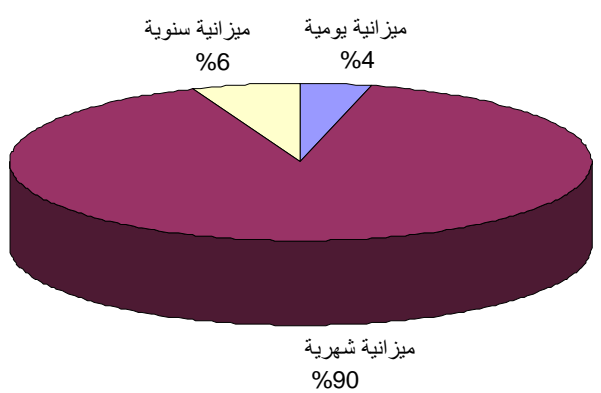

رسهم بياني (10) يوضـح توزيع عينة البحث تبعاً لنوع الميزانية التي تقوم الأسرة بوضعها من حيث المدىى الزمني 
7ا- أسباب عدم عمل ميزانية للدخل المالي للأسرة:

جدول (iی)

\begin{tabular}{|c|c|c|}
\hline النسبـة المئوية & 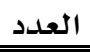 & أسباب عدم عمل ميزانية للدخل المالى \\
\hline ry & 9. & عدم الإلمام بالطريقة الصحيحة لعمل الميزانية \\
\hline$r \varepsilon, \varepsilon$ & 10 & عدم الاهتمام بتخطيط الدخل المالي للأسـرة \\
\hline YT,O & ar & التعود على صـرف الدخل المالي بصورة تلقائية \\
\hline$r$ rel & $\wedge$. & لا ألتزم بالميزانية يِّ حال عملها \\
\hline $1 \cdots$ & $r \varepsilon v$ & المجموع \\
\hline
\end{tabular}

يوضـح جدول (1) بعض العبارات التي تم من خلالها دراسلة أسباب عدم عمل ميزانية للدخل

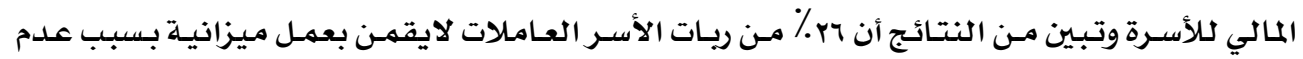

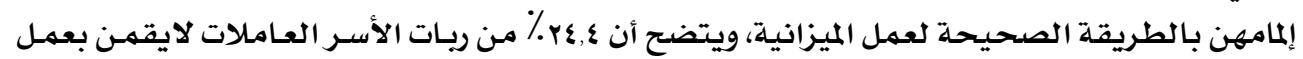

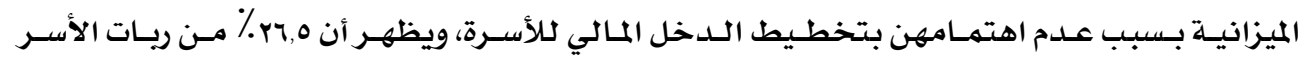

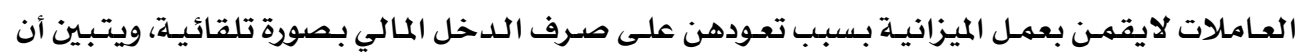

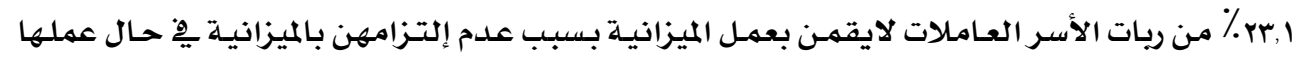

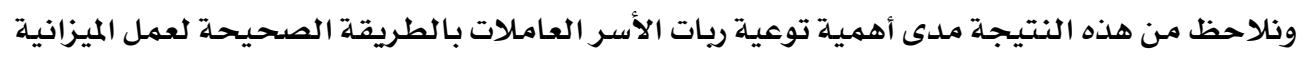

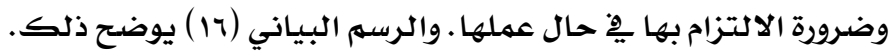

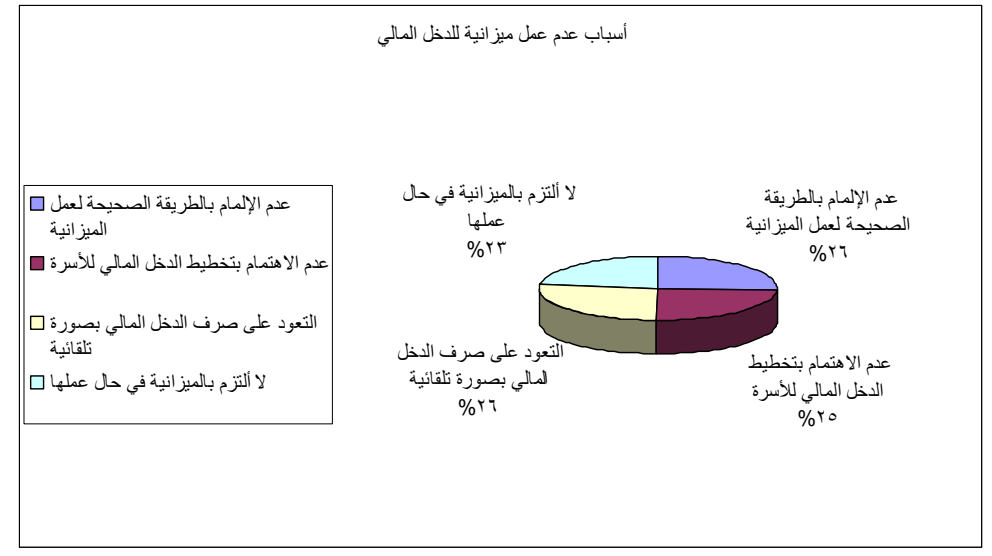

رسمى بياني (1 ا ) يوضح توزيع عينة البحث تبعاً لأسباب عدم عمل ميزانية لدخلها المالي 


\section{التحقق هن صحة الفروض:}

الفرض الأول:

توجد علاقة ارتباطية موجبة بين بعض المتفيرات الاجتماعيـة والاقتصادية كلأسـرة وأبعاد

الدور الاقتصادي كربة الأسرة العاملة.

وللتحقـق مـن صسحة هـذا الفـرض تم إيجـاد مـصفوفة معـاملات الارتبـاط بــين أبعـاد الـدور

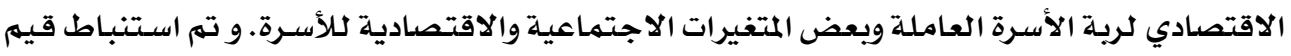

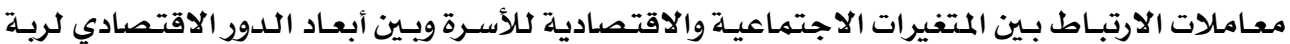

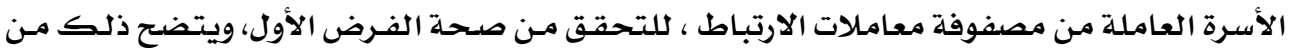
جدول (19). 
جدول بالعرض 
يتضـح من الجـدول (19) ) عدم وجـود علاقـة ارتباطيـة بـين المتغيرات الاجتماعيـة والاقتصادية

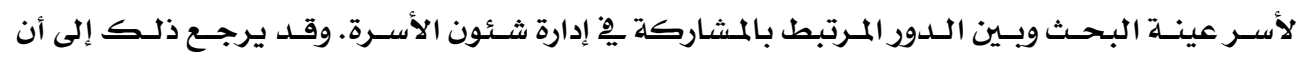

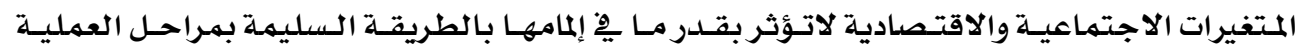

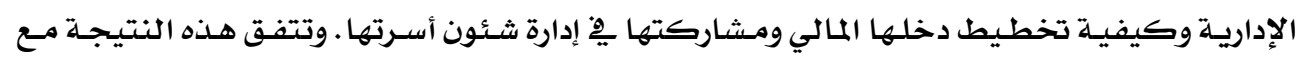

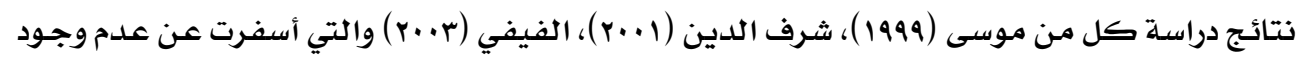

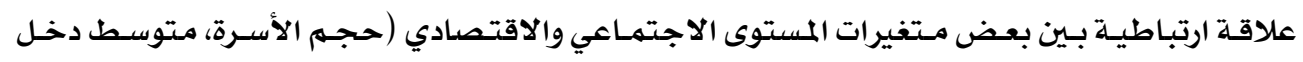
الأسرة، عمر الزوجين، وظيفة الزوجينين) وإدارة الدخل المالمالي للأسرة.

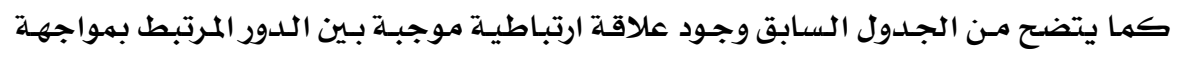

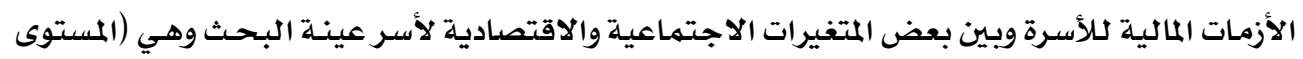

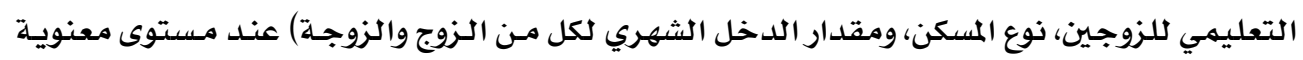

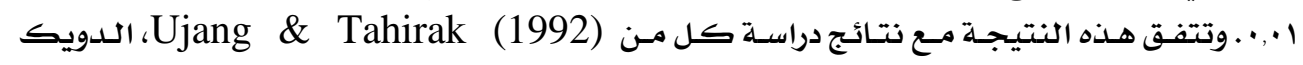

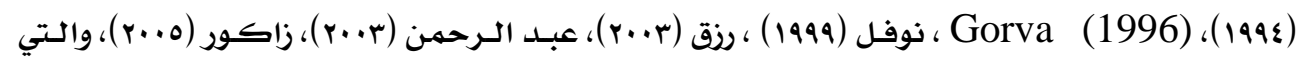

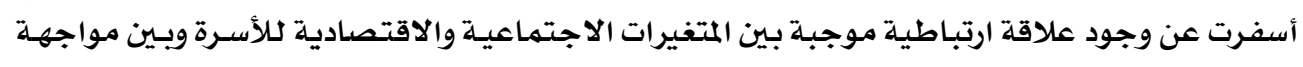
الأزمات المالية للأسرة.

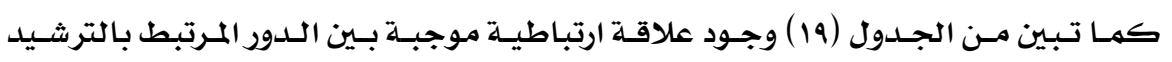

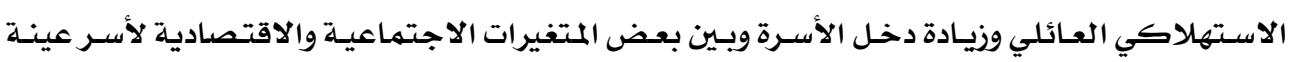

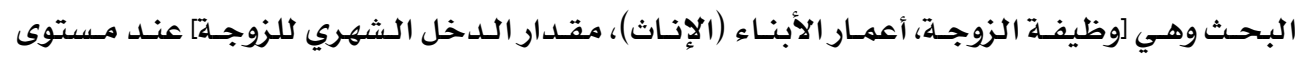

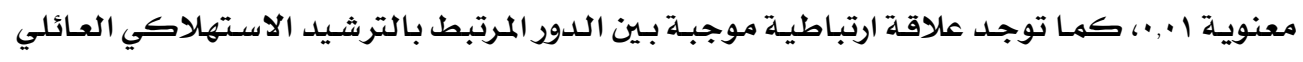

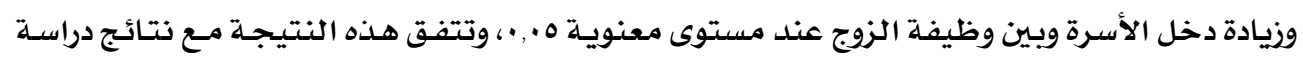

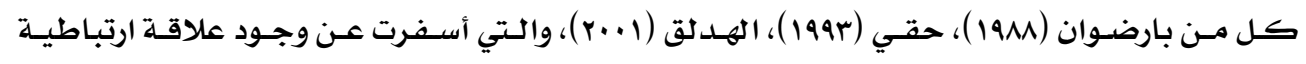

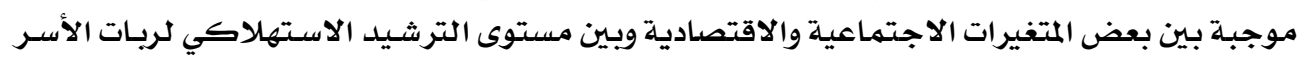
العاملات ومدى وعيهن الاستهلاكي. بعض المتفيرات الاجتماعية

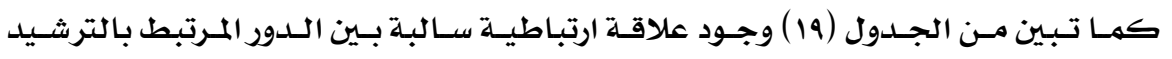

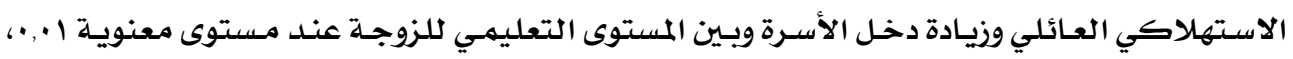

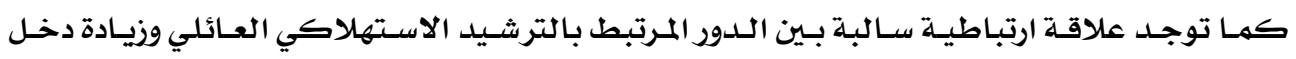

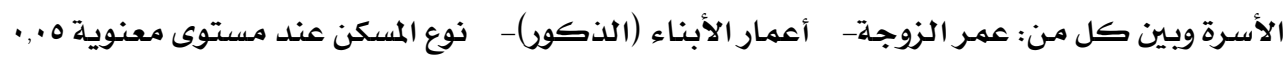
كما يكشف الجـدول السابق عن وجـود علاقة ارتباطيـة موجبـة بـين الدور المرتبط بالادخـار

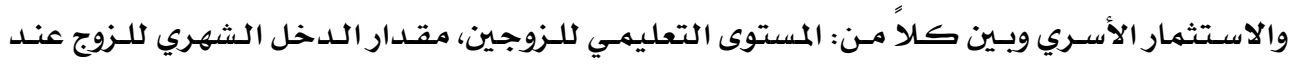

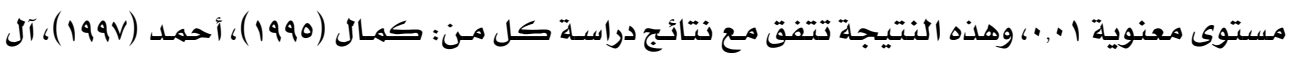

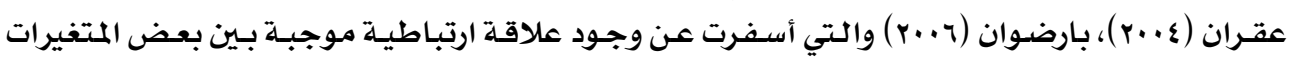
الاجتماعية والاقتصادية وبين الميل للادخار والاستثمار الأسري. 
كما تبين وجود علاقة ارتباطية سالبة بين الدور المرتبط بالادخـار والاستثمار الأسـري وبـين

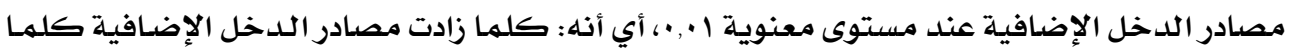

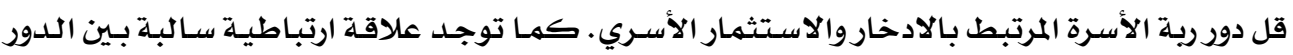

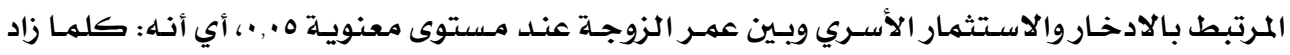

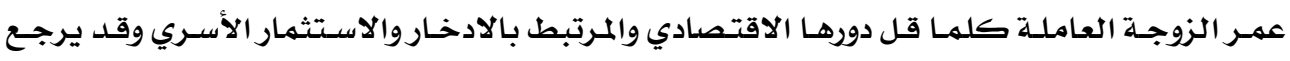

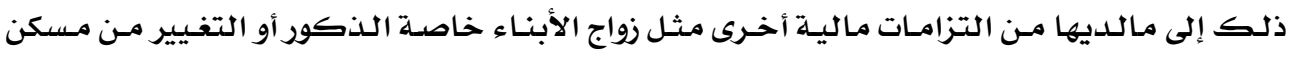

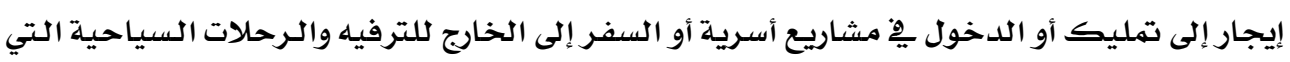

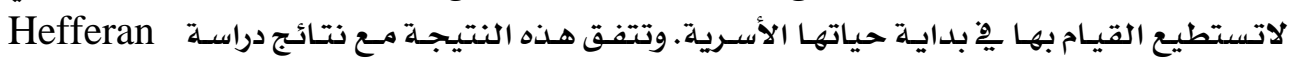

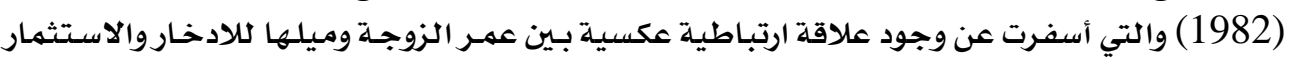

كما نلاحظ من الجدول (19) وجود علاقة ارتباطية سـالبة بـين الدور المرتبط بالمسـاهمة يو

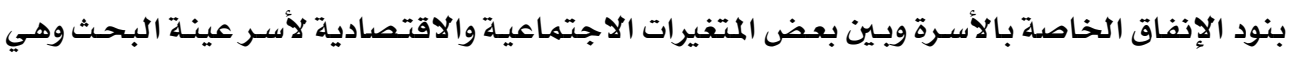

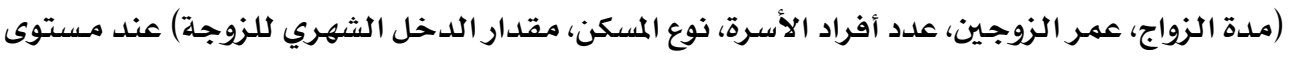

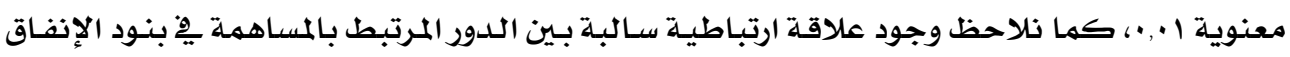

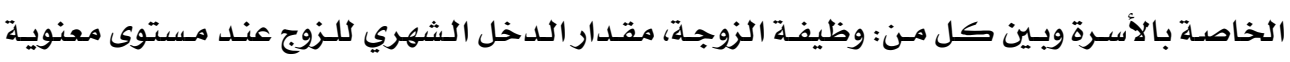

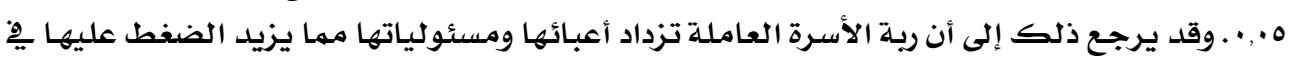

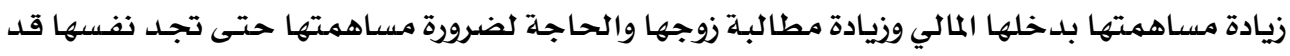

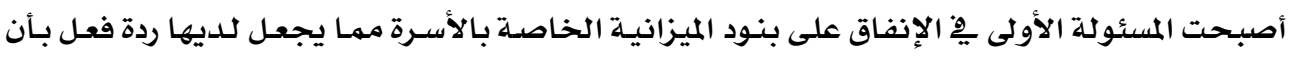

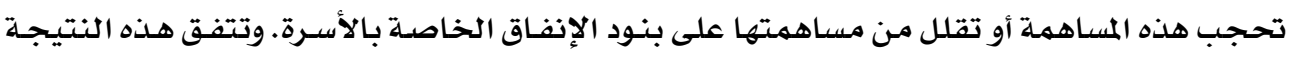

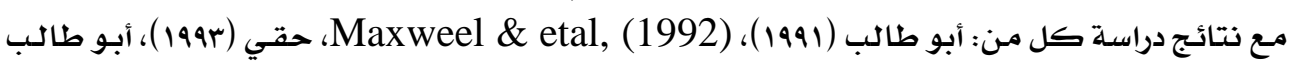

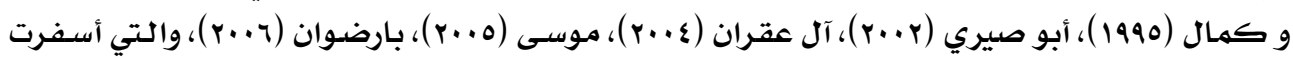

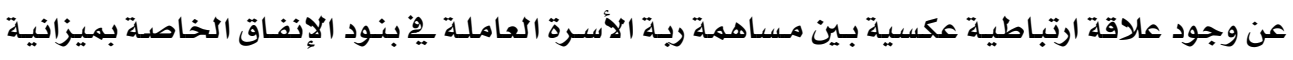

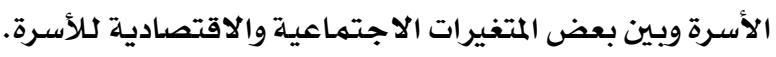

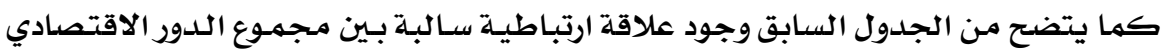

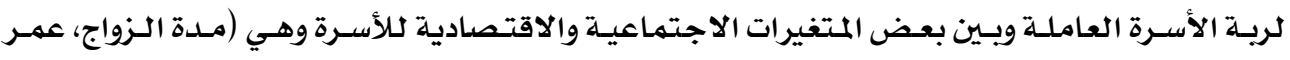

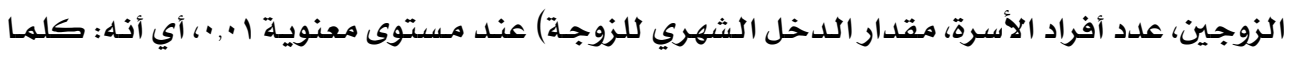

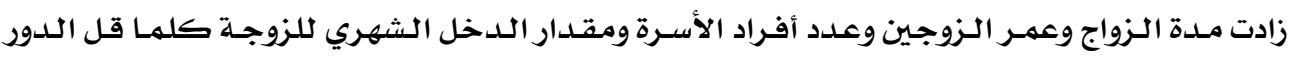

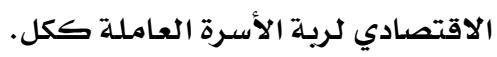

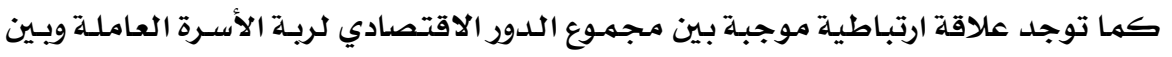

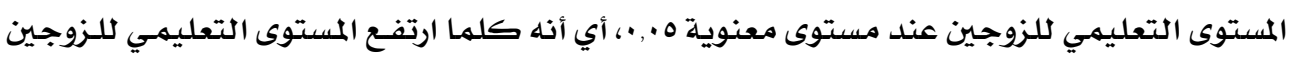

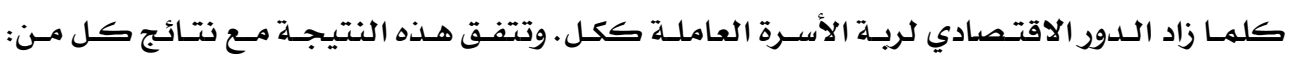
Patricia \& Others (1989)، Beuttler \& Meson (1987)، Fanning (1981) 


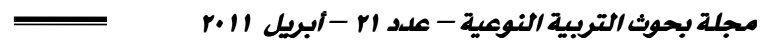

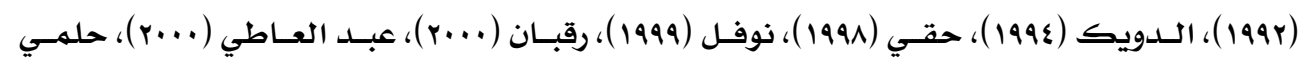

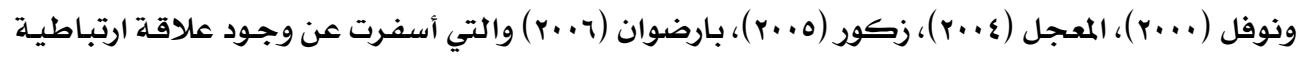

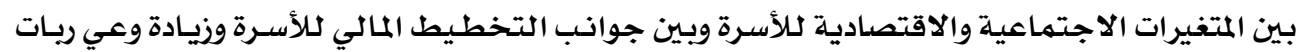

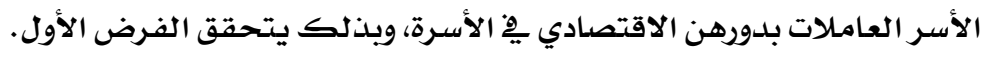

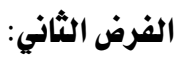
توجد علاقة ارتباطية موجبة بين بعض المتغيرات الاجتماعية والاقتصادية كلأسـرة، وبـين محاور التوافق الزواجي. توجل علاجة ارتبام

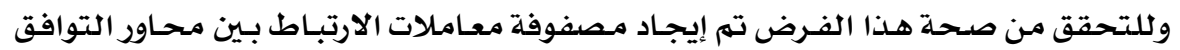

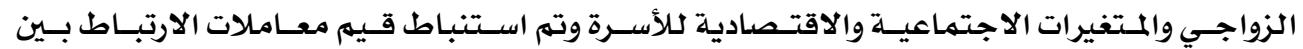

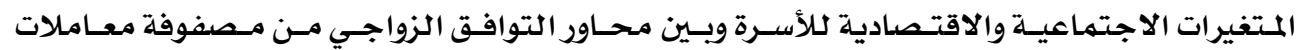

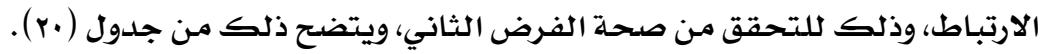




$$
\text { جدول بالعرض }
$$




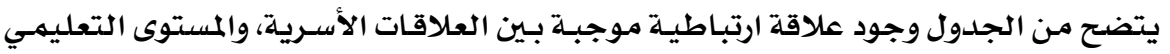

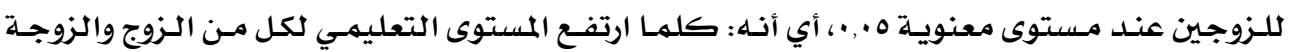

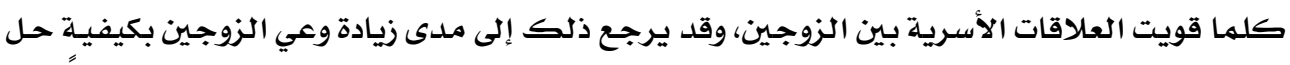

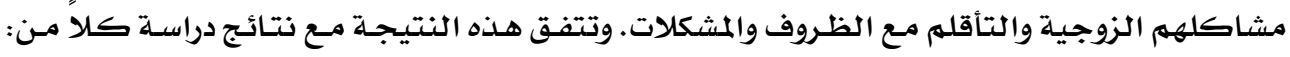

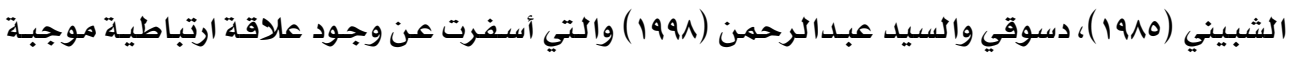

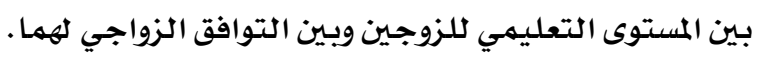

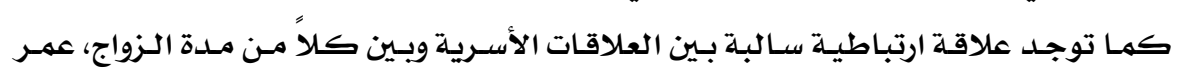

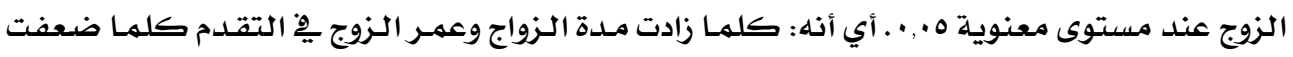

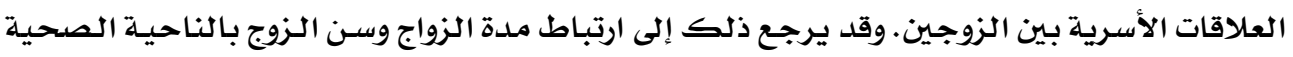

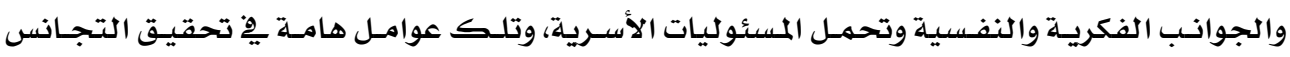

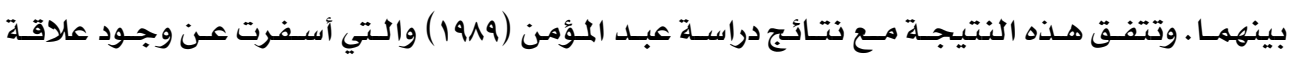

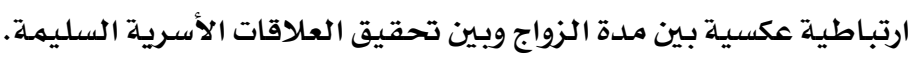

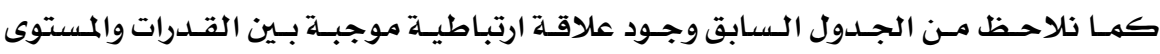

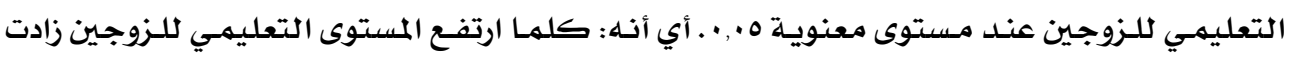

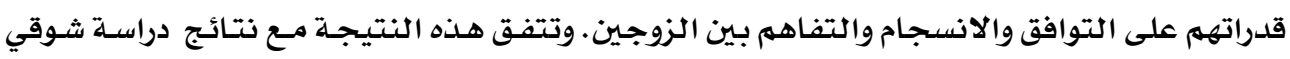

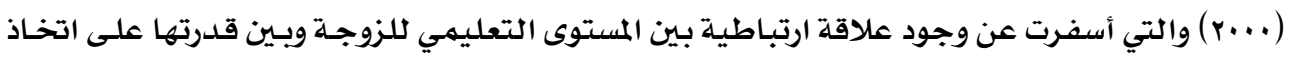
القرارات وتحقيق التوافق الزواجي.

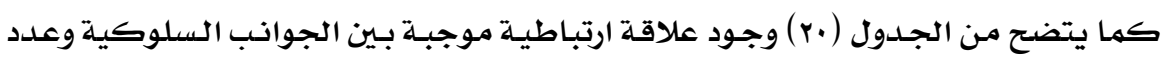
أفراد الأسرة عند مستوى معنوية ه.... كمها يكشف الجــدول السـابق عن عدم وجـود علاقـة ارتباطيـة بـينِ السيطرة وبـين المتغيرات

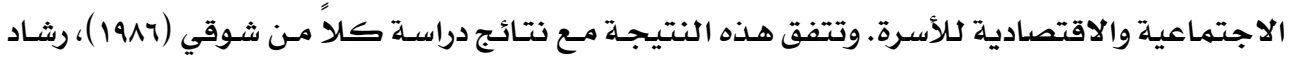

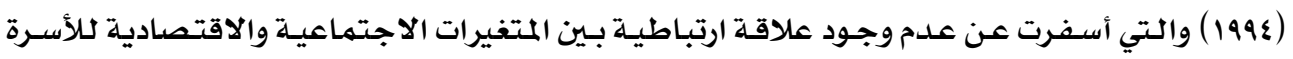

$$
\text { وبين مستوى السيطرة. }
$$

كما نلاحظ وجود علاقة ارتباطية سالبة بين الأمـور العاطفيـة والجنسيـة وبـين مـدة الزواج،

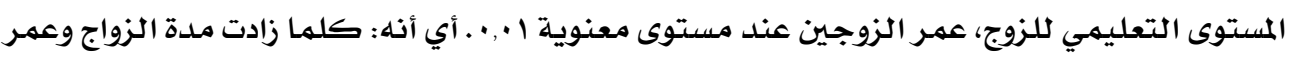

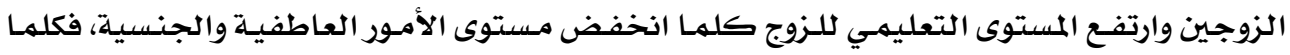

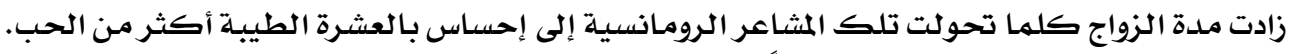

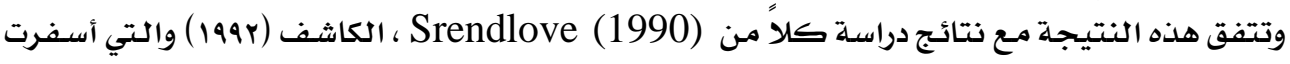

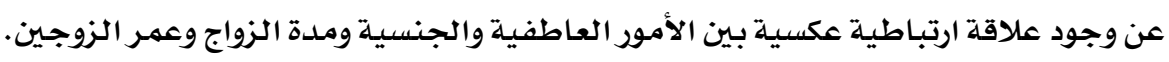

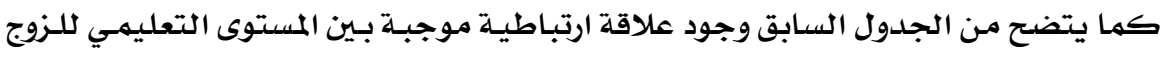

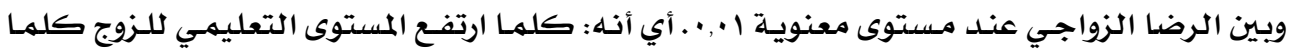

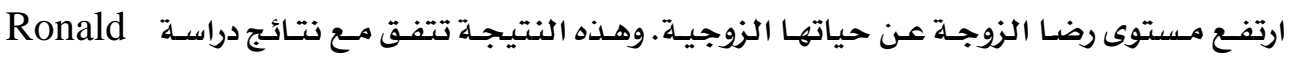


(1976) والتي أسفرت عـن وجـود علاقـة ارتباطيـة بـين المستوى التعليهـي للـزوج وبـين الرضـا الزواجـي للزوجـة.

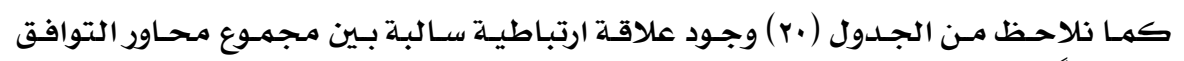

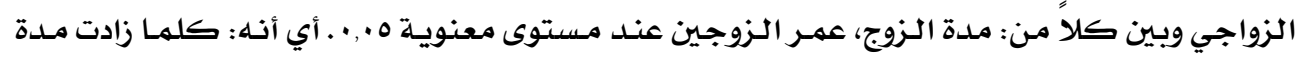

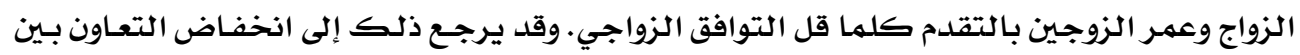

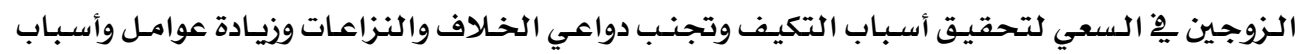
التوافق والانسجام التوجن

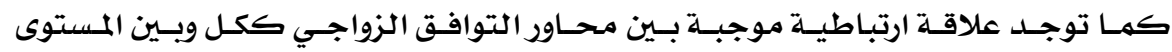

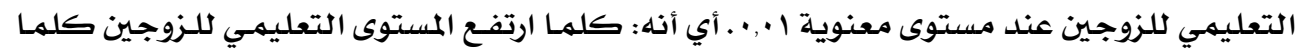

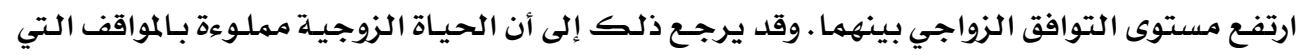

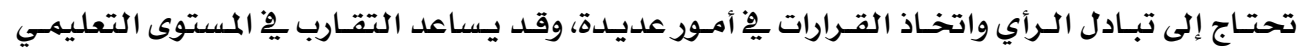

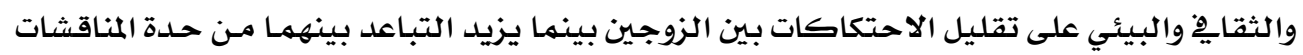

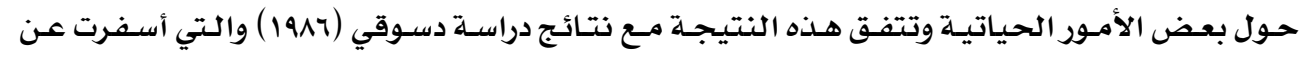

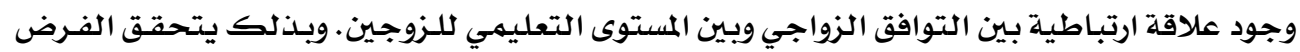

توجد علاقة ارتباطية موجبة بين بعض أبعاد الدور الاقتصادي لربة الأسرة العاملة، وبعض الرض

محاور التوافق الزواجي.

وللتحقـق مـن صـحـة هـــا الفـرض تم إيجـاد مـصفوفة معـامـلات الارتبـاط بـين أبعـاد الــدور

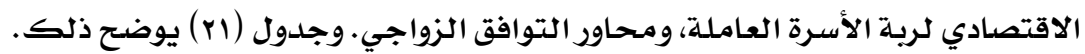




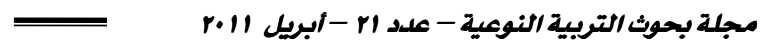

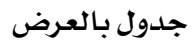




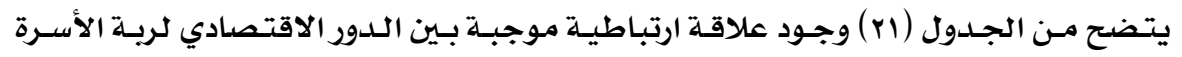

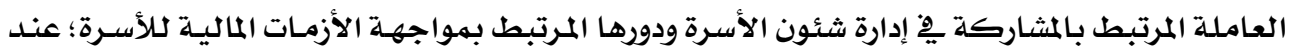

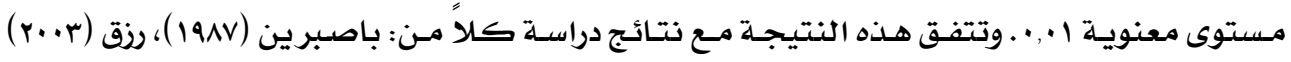

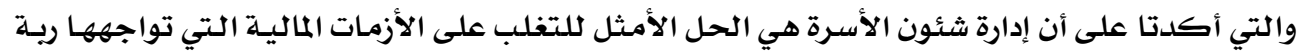

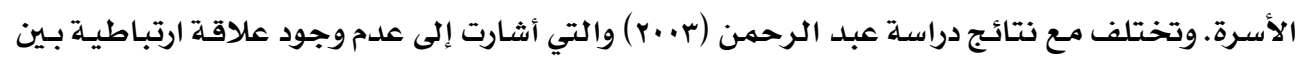

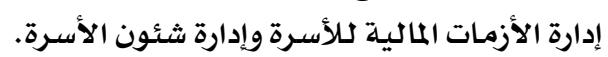

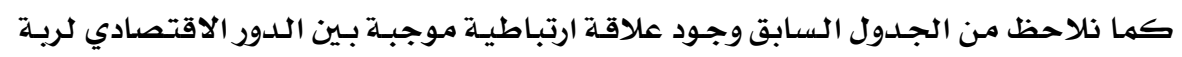

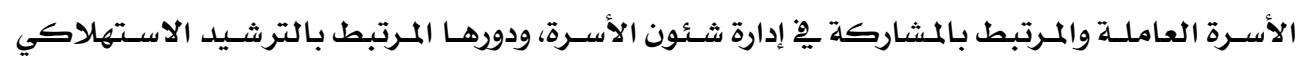

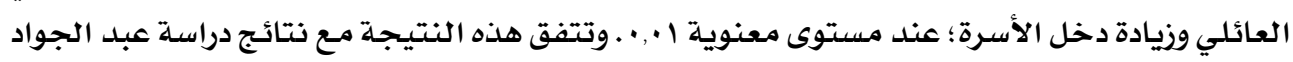

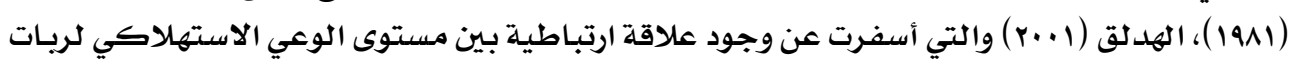

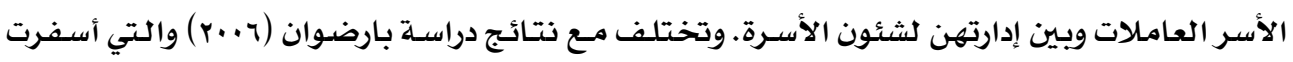

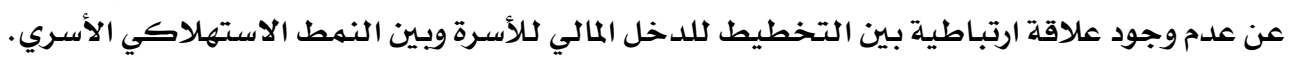

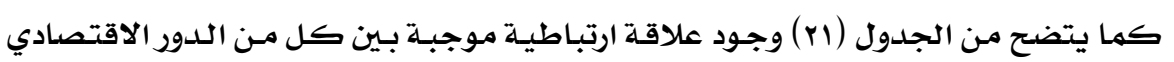

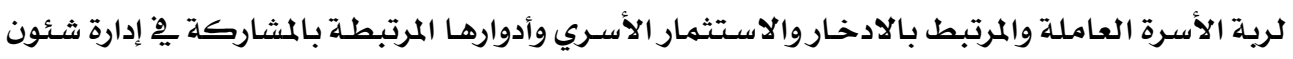

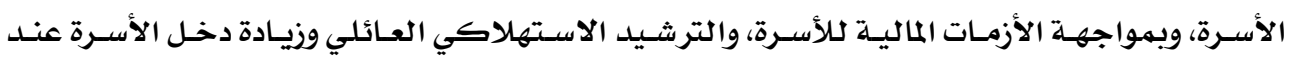

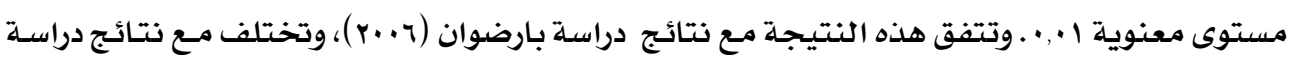

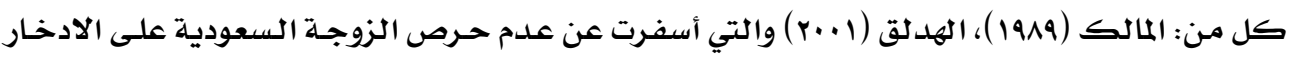

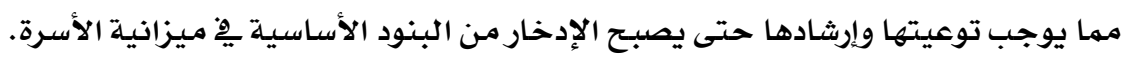

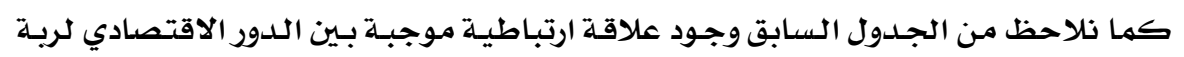

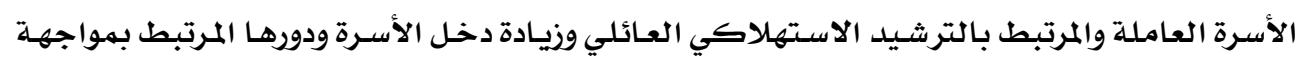

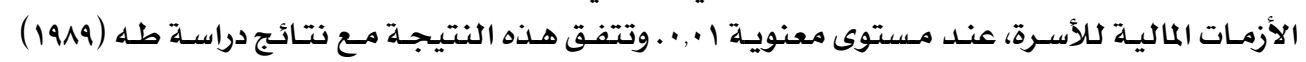

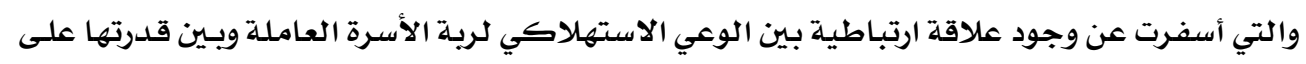
مواجهة الأزمات المالية لكلأسرة.

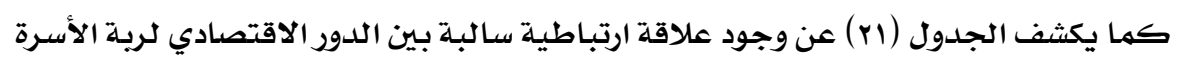

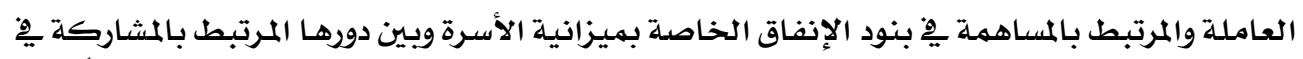

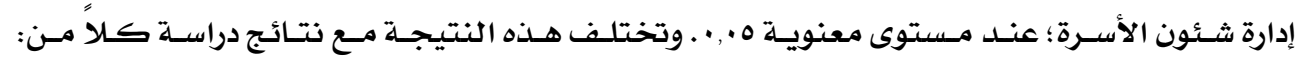

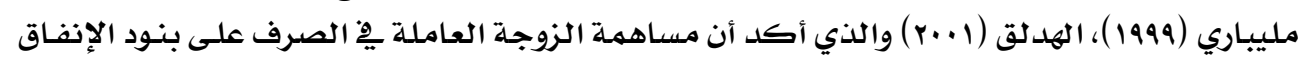

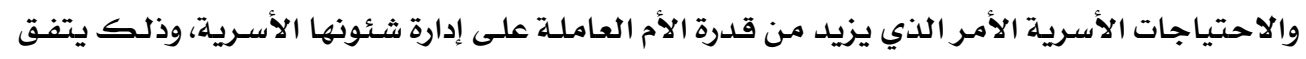

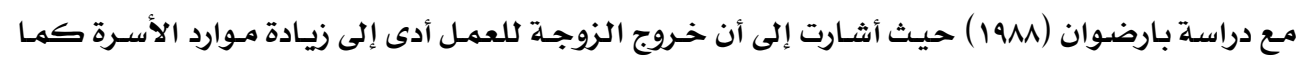

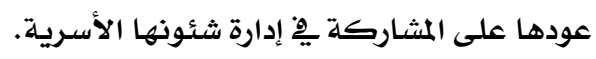

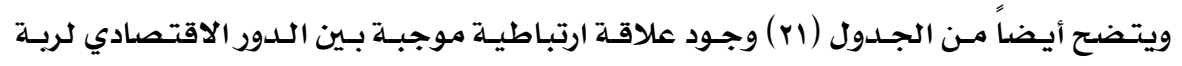

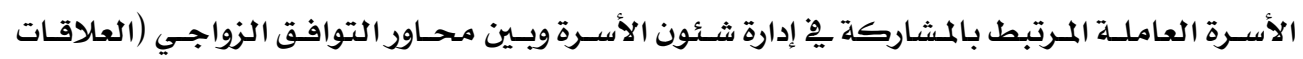




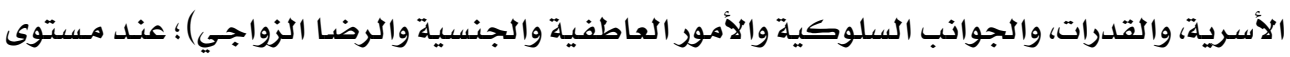

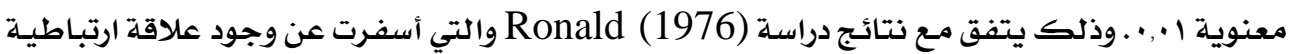

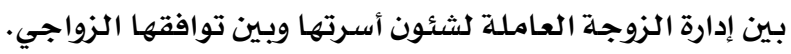

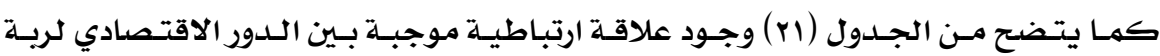

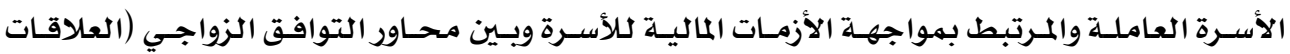

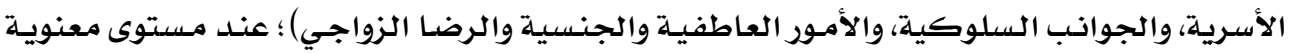

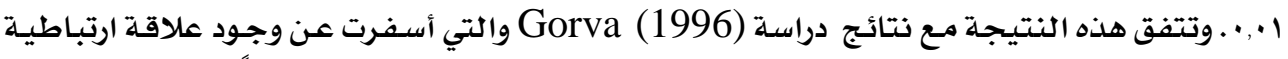

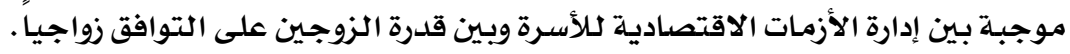
كما توجد علاقة ارتباطية موجبـة بـين الددور المرتبط بمواجهـة الأزمات الماليـة للأسـرة وبـين

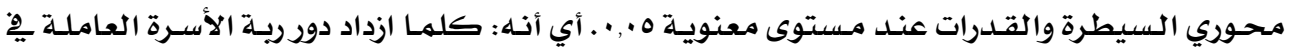

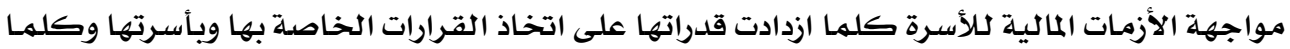
ازدادت السيطرة.

كما نلاحظ من الجـدول السـابق وجـود علاقة ارتباطيـة موجبـة بـين الدور الاقتصـادي لريسة

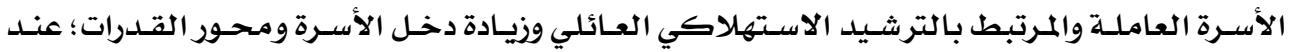

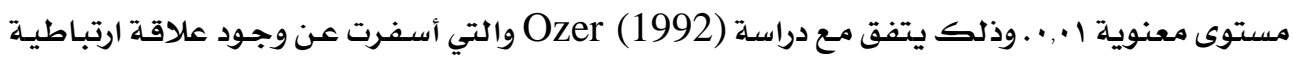

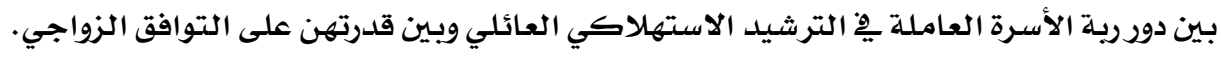

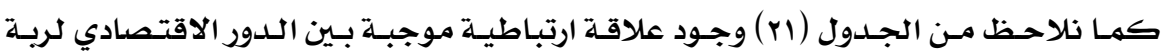

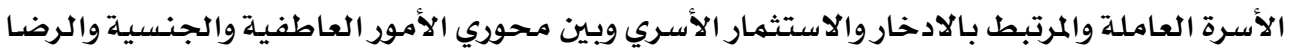

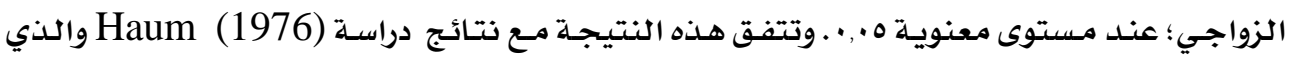

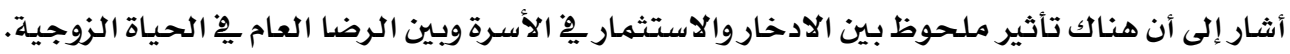
كما يتبين من الجدول (r^) وجود علاقة ارتباطية موجبة بين الدور الاقتصادي لرية الأسرة

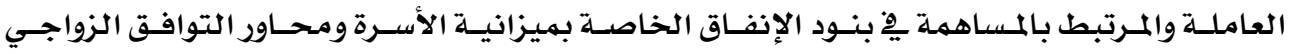

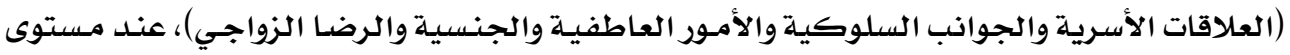

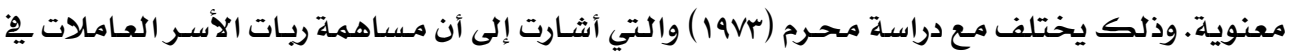

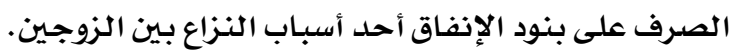

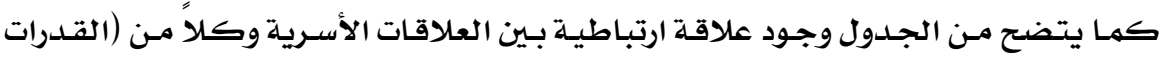

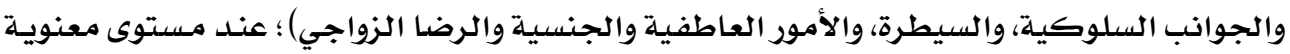

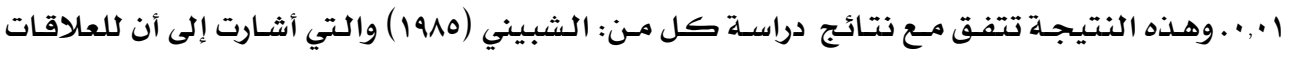

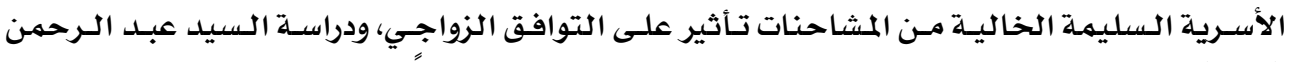

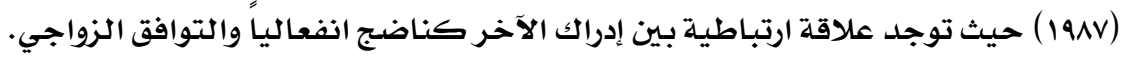


كما نلاحظ من الجدول السابق وجود علاقة ارتباطية سالبة بين السيطرة وكلاً من الأمور

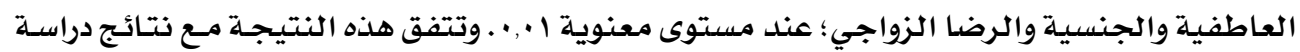
رشاد (ع919) التي أكدت وجود علاقة ارتباطية عكسية بين السلطة الزواجية وبين التوافق الزواجي.

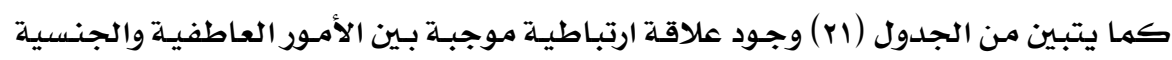

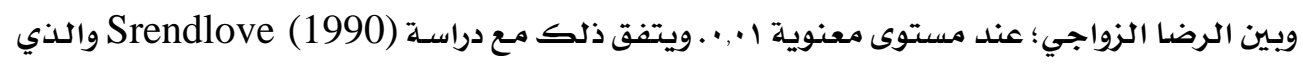

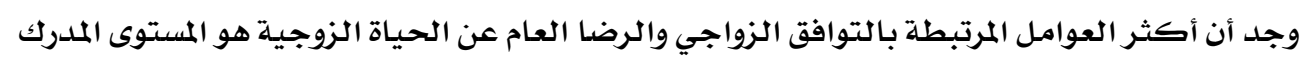

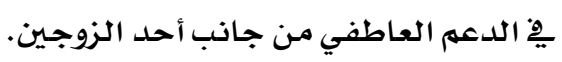

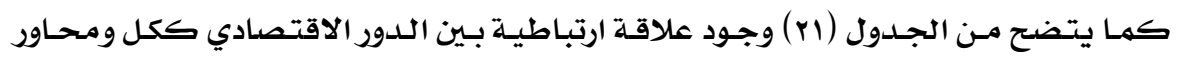

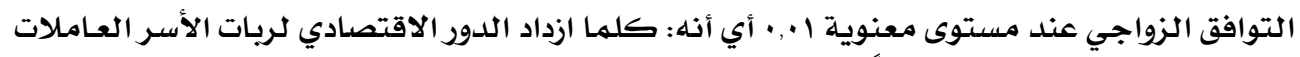

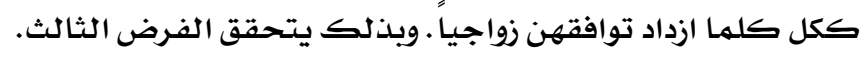

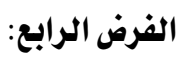

توجد فروق ذات دلالة إحصائية ِِّ محاور التوافق الزواجي بين ريات الأسر المساهمات وغير

المساهمات ِِّ بنود الإنفاق المختلفة.

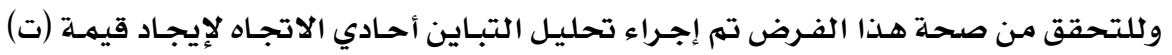

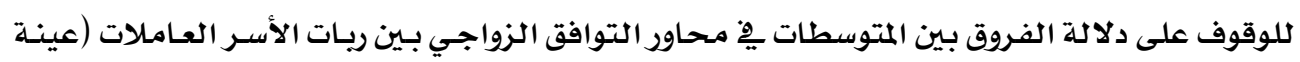

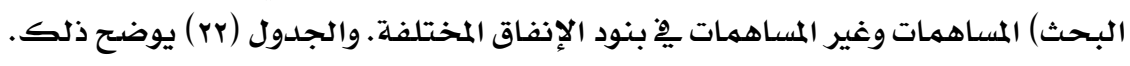

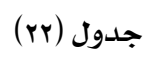

تحليل التباين ِِّ محاور التوافق الزواجي بين ربات الأسر المساهمات وغير المساهمات ِِّ بنود الإنفاق

\begin{tabular}{|c|c|c|c|}
\hline مستوى الدلالة & اختبار (ت) & قيمة (ت) & مححاور التوافق الزواجي \\
\hline غير دال & ras & $1,1 \wedge \varepsilon-$ & العلاقات الأسـريـة \\
\hline غير دال & ras & $\cdot, \Lambda Y \wedge$ & القدرات \\
\hline غير دال & ras & $\cdot, 1 \wedge 9 \quad-$ & الجوانب السلوكية \\
\hline غير دال & ras & $\cdot, \wedge 79$ & السيطرة \\
\hline 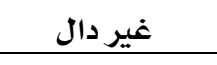 & ras &., $191 \quad-$ & الأمور العاطفية والجنسية \\
\hline غير دال & ras & .,YYT - & الرضسا الزواجي \\
\hline
\end{tabular}

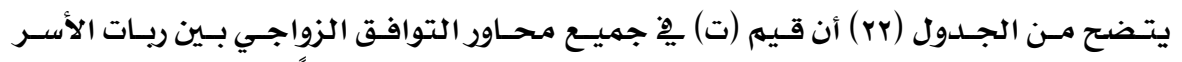

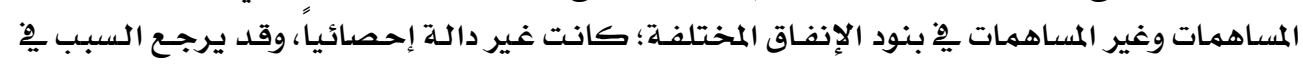

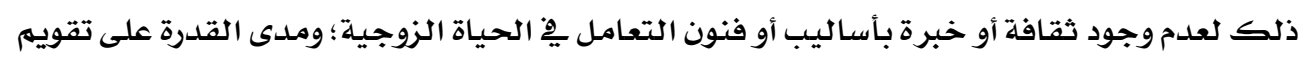

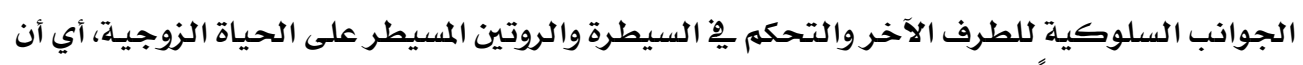

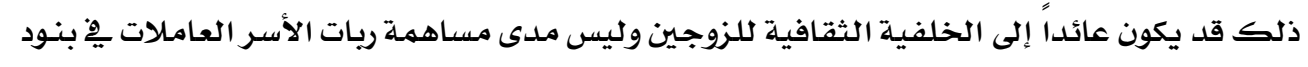


الإنفـاق المختلفـة، وترى البـاحثة أن التطور التقني قـد أسهـهم بشكل فعـال فيمـا توصلت إليـه الدراسـة،

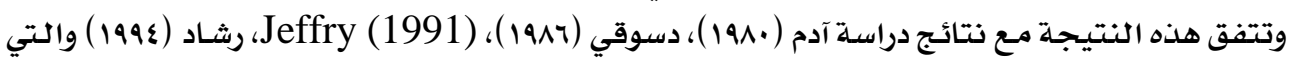

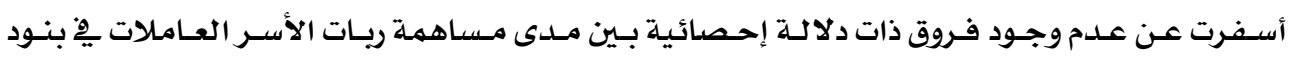

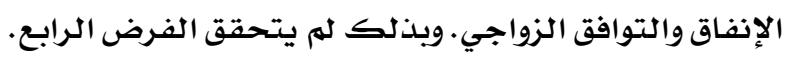

\section{همص النتائج:}

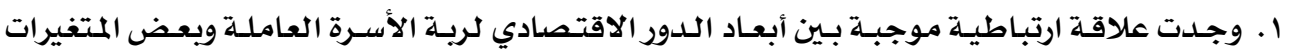

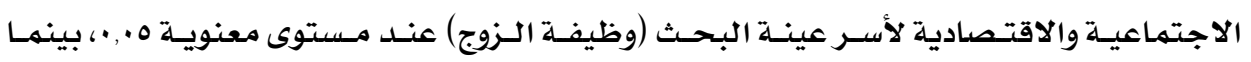

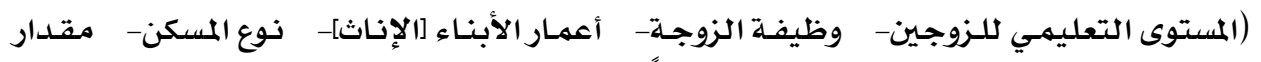

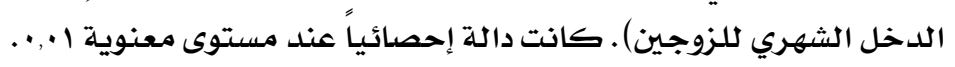

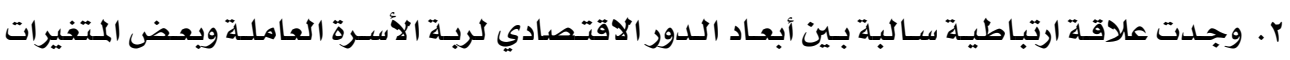

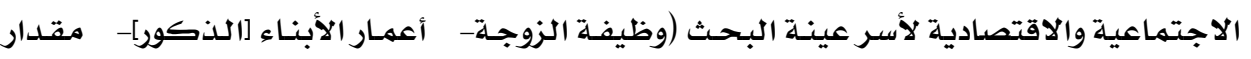

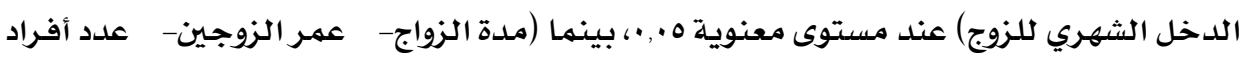

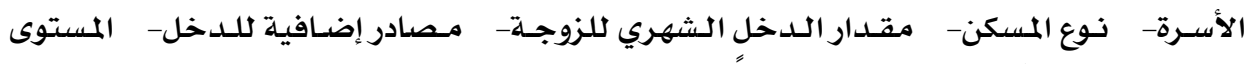

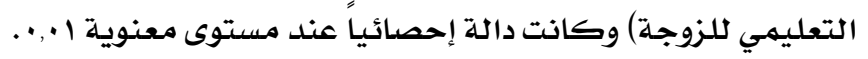

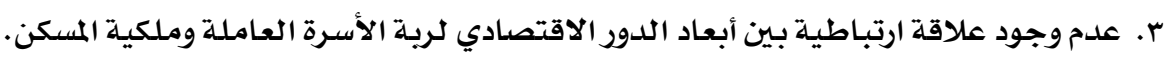

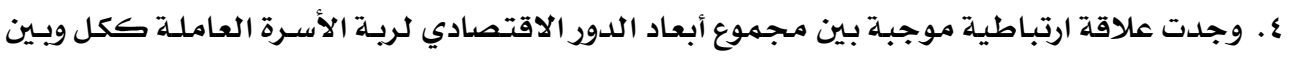

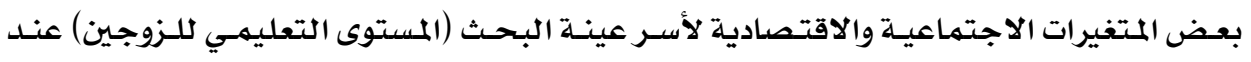
مستوى معنوية ه.,.•. هـ وجدت علاقة ارتباطية سالبة بين مجمهوع أبعـاد الدور الاقتصـادي لربـة الأسـرة العاملـة ككل وبـين

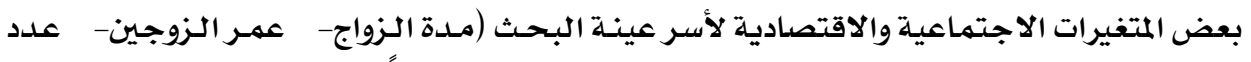

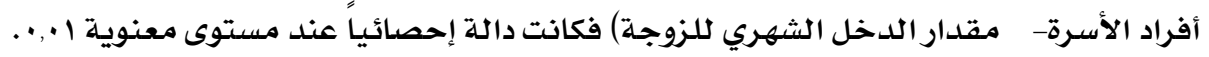

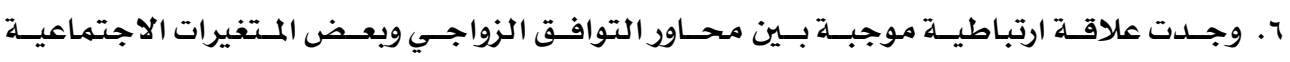

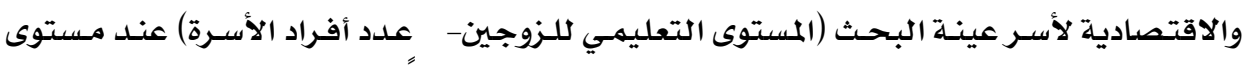

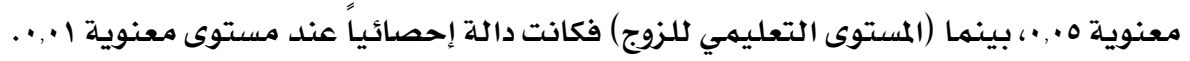

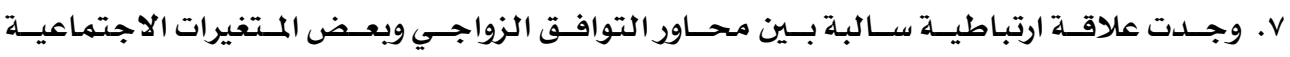

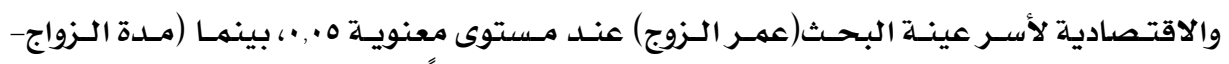

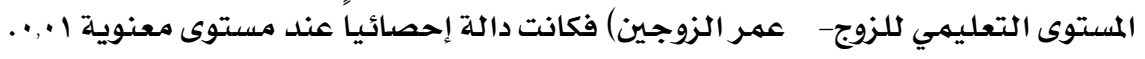

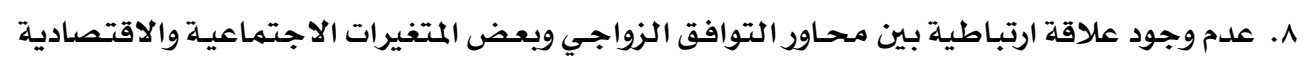

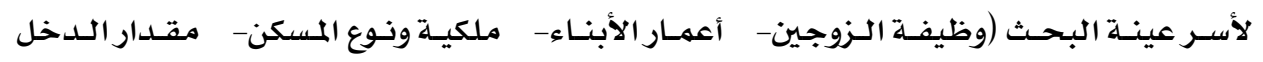

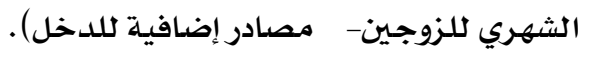

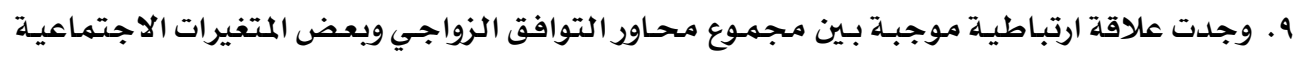

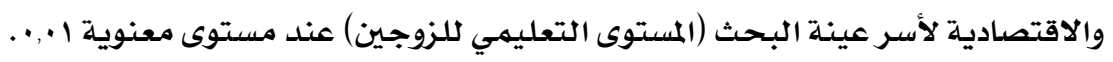


• ا.وجـدت علاقـة ارتباطيـة سـالبـة بـين مجهـوع محساور التوافق الزواجـي وبعض المتتغيرات الاجتماعيـة

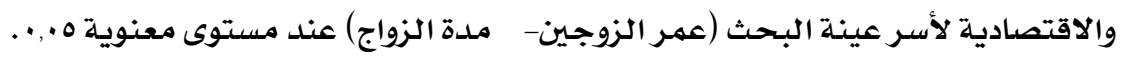

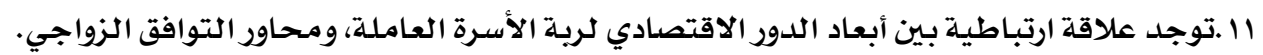

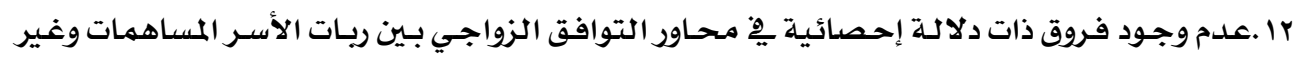

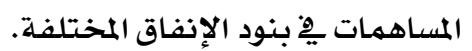

التوصيات:

بناء على النتائج التي تم التوصل إليها بالدراسة الميدانية توصي الباحثة بالتالي:

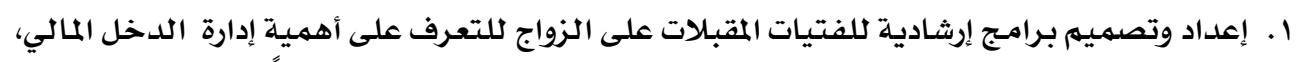

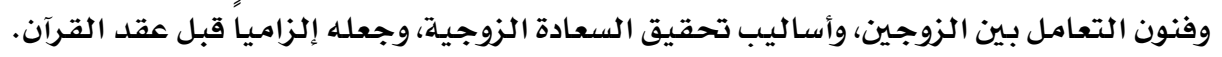

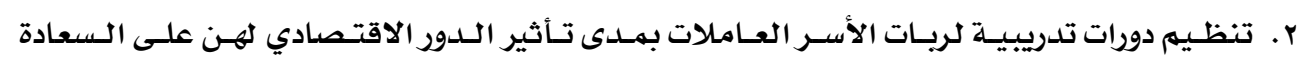

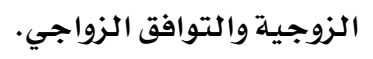

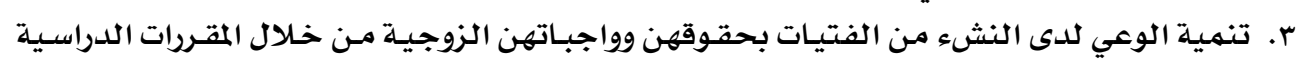

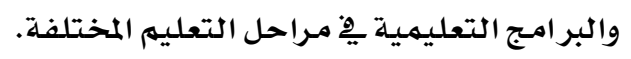

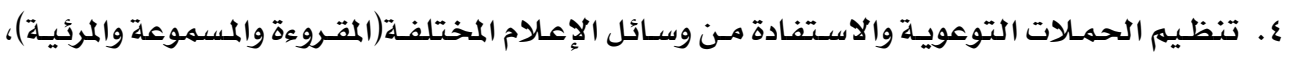

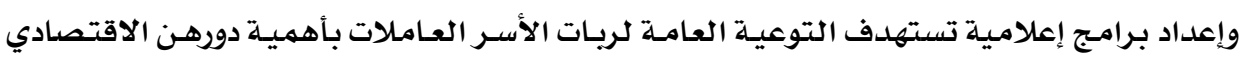

ومدى تأثيره على توافقهن الزواجي. 


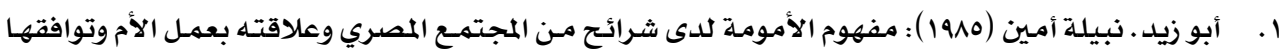

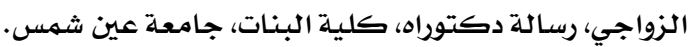

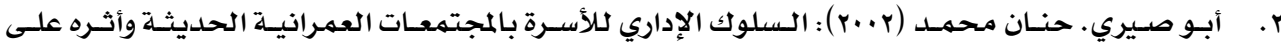
اقتصادياتها، رسالة دكتوراه، كلية الاقتصاد المنزلي، جامعة حلوان.

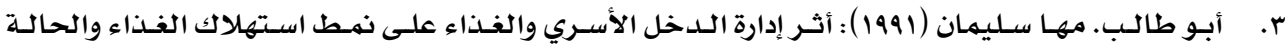

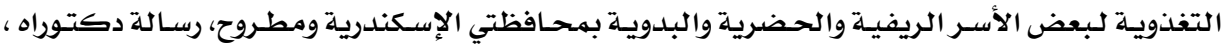
قسم الاقتصاد المنزلي، كلية الزراعة، جامعة الإسكندرية.

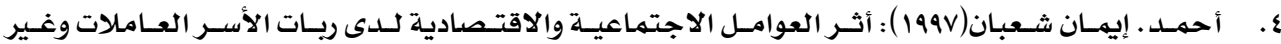

العاملات على أنماط السلوك الادخاري، رسالة ماجستير ، كلية الاقتصاد المنزلي، جامعة المنوفية.

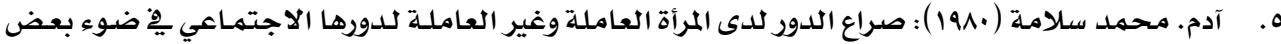
السمات الشخصية، رسالة ماجستير، كلية الآداب، جامعة عين شمس.

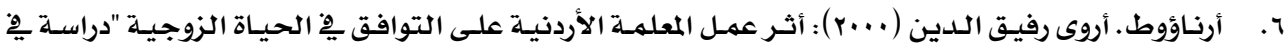
منطقة عمان"، رسالة ماجستير، كلية الدراسات العليا، الجامعة الأردنية.

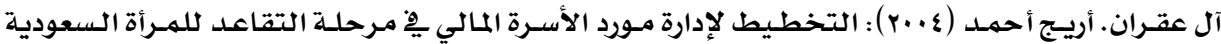
العاملة، رسالة ماجستير، قسم السكن وإدارة المنزل، كلية التربية للاقتصاد المنزلي والتربية الفنية، جدة.

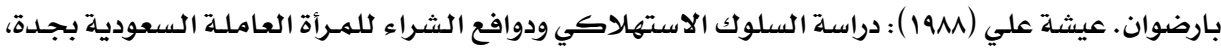

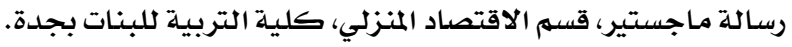

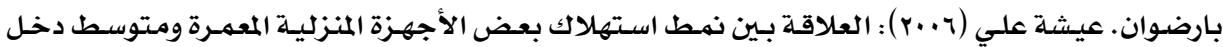

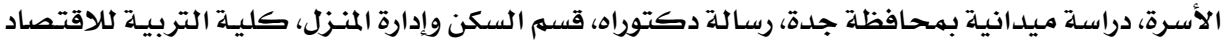
المنزلي والتربية الفنية بجدة.

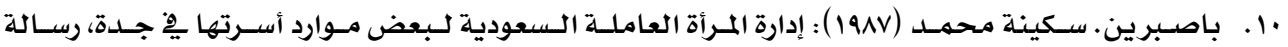

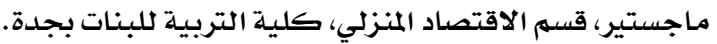

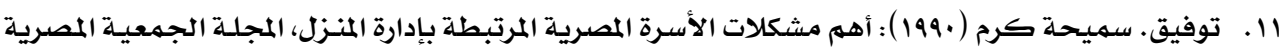
للاقتصاد المنزلي، العدد ا، جامعة حلوان.

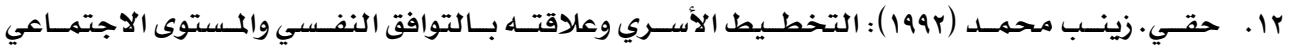

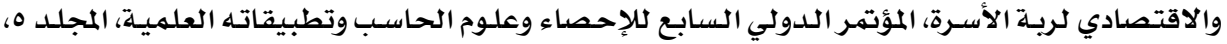
مركز الحاسب العلهي، جامعة عين شمس.

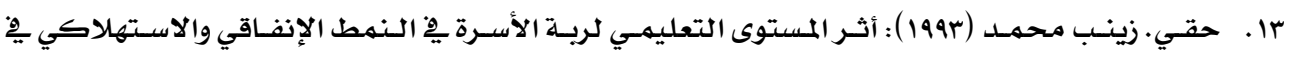

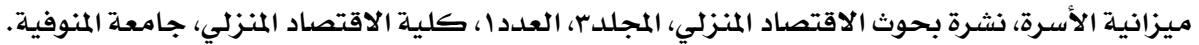

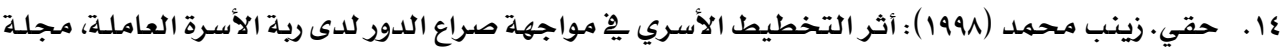

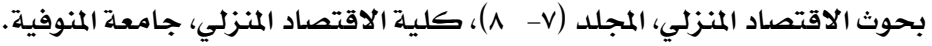


10 حقي. زينب محمد و أبو سكينة. نادية حسن (1991) ؛ علاقة إدارة مـوارد الأسـرة بصعوبات التوافق النفسي

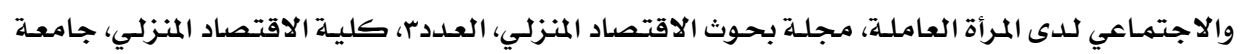
المنوفية.

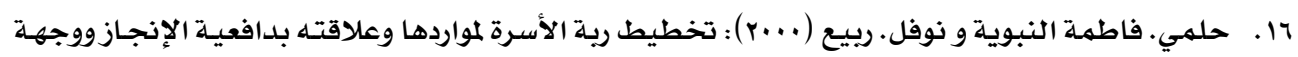

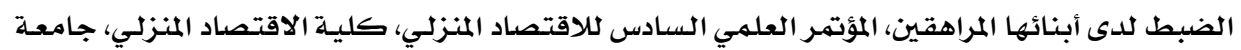
حلوان.

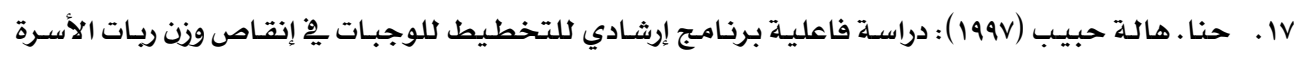
ذوات السمنة المفرطة، دراسـة تجريبية، رسالة ماجستير، كلية الاقتصساد المنزلي، جامعة حلوان. 11. دسوقي. راوية محمود (1911) : التوافق الزواجي، رسالة دكتوراه، كلية الآداب، جامعة الزقازيق.

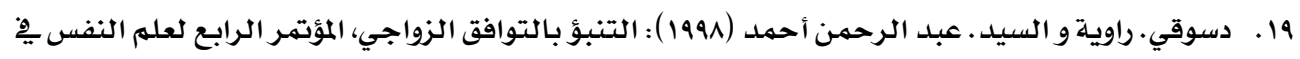
مصر، مركز التنمية البشرية والمعلومات، الجيزية.

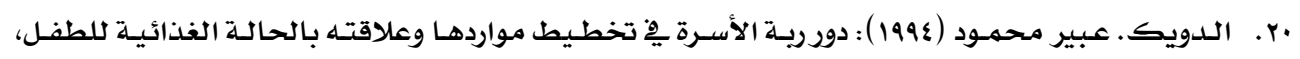
رسالة ماجستير ، كلية الاقتصاد المنزلي، جامعة المنوفية.

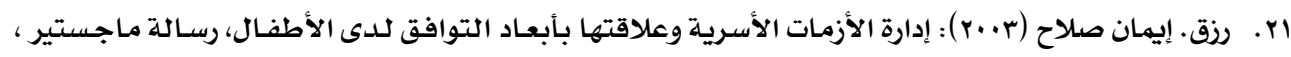
كلية الاقتصاد المنزلي، جامعة المنوفية.

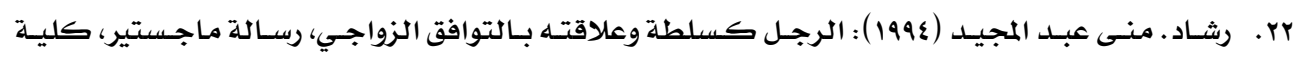
الآداب، جامعة عين شمس. ريس.

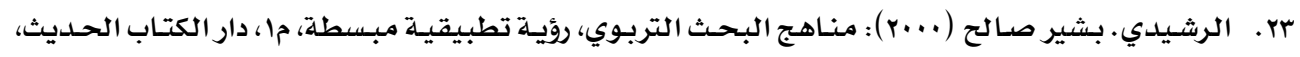
القاهرة.

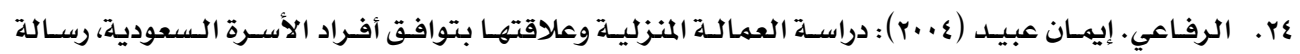
ماجستير، قسم السكن وإدارة المنزل، كلية التربية للاقتصاد المنزلي بمكة المكرمـة.

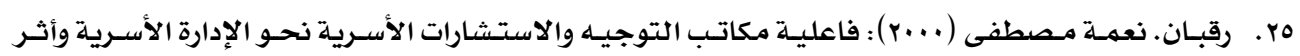
ذلك على المنـاخ الأسـري، المؤتمر السنوي الخـامس لإدارة الأزمـات والكـوارث، كليـة التجـارة، جـامعـة عـين شمس.

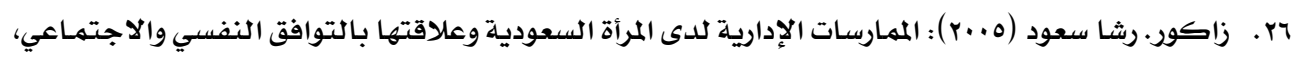
رسالة ماجستير، كلية الاقتصاد المنزلي، جامعة حلوان.

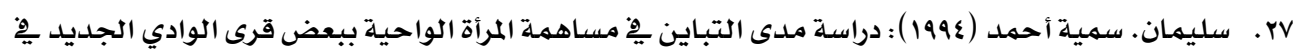

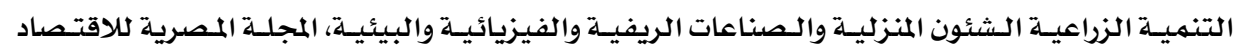
المنزلي، العدد · 1، كلية الاقتصاد المنزلي، جامعة حلوان.

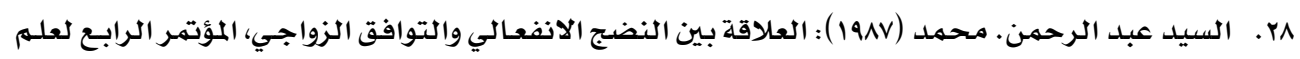
النفس ِِّ مصر، مركز التتميـة البشرية والمعلومات، الجيزة. 


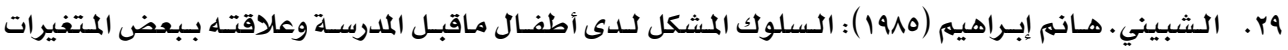
الأسـريـة، رسـالة مـاجستير، قسهم الدراسـات النفسية والاجتمعاعيـة معهد الدراسـات العليـا للطفولـة، جامعـة عين شمس.

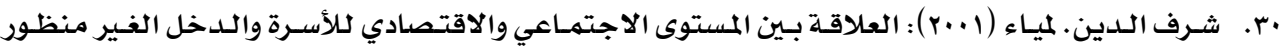
لعمل الزوجة المنزلي، رسالة ماجستير، قسه الاقتصاد المنزلي، كلية التربية النوعية، جامعة عين شمس.

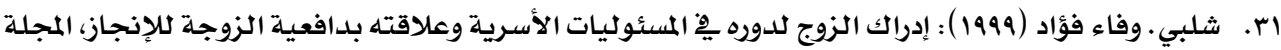
المصرية للاقتصاد المنزلي، العددها ، كلية الاقتصاد المنزلي، جامعة حلوان. r.r. شوقي. كمال مصطفى (71911 ): عله النفس ودراسة التوافق، دار النهضة العربية، القاهرة.

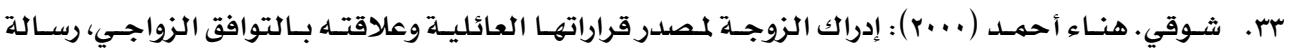
ماجستير، قسم إدارة مؤسسـات الأسـرة والطفولة، كلية الاقتصاد المنزلي، جامعة حلوان. گr. طـه. سـلوى محمـل (1919) : السـلوك الاسـتهلاكي للطفـل المصري وأثره على اقتصـاديات الأسـرة، رسـالة ماجستير، قسه إدارة المنزل، كلية الاقتصاد المنزلي، جامعة حلوان. هr. عبد الجواد. نجوى سيد (1911) ): أثر خـروج المرأة للعمـل على نهط استهلاك الأسـرة واقتصادياتها، رسـالة ماجستير ، كلية الاقتصاد المنزلي، جامعة حلوان.

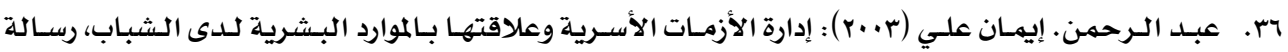
دكتوراه ، كلية الاقتصاد المنزلي، جامعة المنوفية.

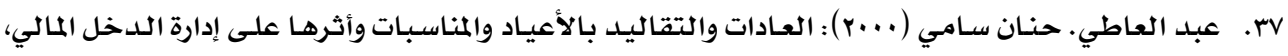
دراسـة ميدانية يخ حضر محافظة الدقهلية، رسالة ماجستير، كلية الاقتصاد المنزلي، جامعة حلوان.

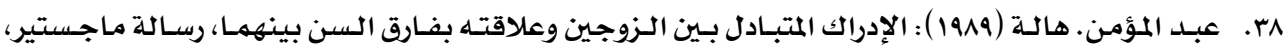
كلية الآداب، جامعة عين شمس. هr. عبد المعطي. سـوزان محمدل (1991) ): توقعات الشبـاب قبـل الزواج وبعـده وعلاقتهـا بـالتوافق الزواجي، دراسـة ميدانية، رسالة ماجستير ، كلية الآداب، جامعة عين شمس.

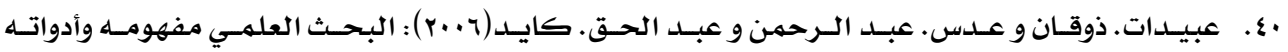
وأساليبـه، دار أسـامـة للنشر والتوزيع، جدة.

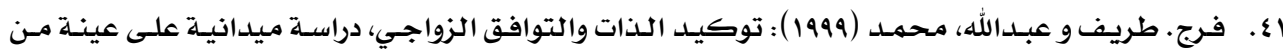
الأزواج المصريـين، المجلة العربية للعلوم الإنسانية، العددلاج، القاهرة.

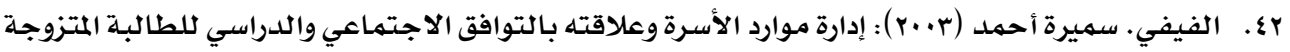
بالمرحلـة الجامعيـة، رسـالة مـاجستير ، قسهم السكن وإدارة المنـزل، كليـة التربيـة للاقتصـاد المنزلسي، بهكـة المكرمـة.

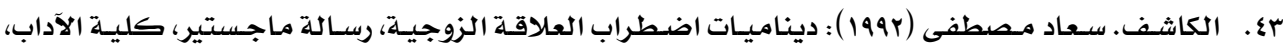
جامعة عين شمس.

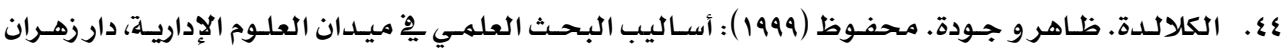
للنشر والتوزيع ، الأردن. 
0؛. كمـال. فـاتن مـصطفى (1990) ) أثر العوامـل الاقتصـادية والاجتماعيـة لكلأسـرة المصريـة على الأنهـاط الاستهلاكية، رسالة دكتوراه، كلية الاقتصـاد المنزلي، جامعة المنوفية.

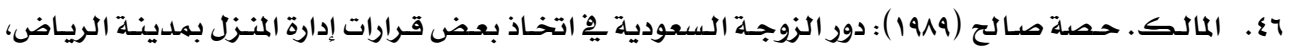
رسالة دكتوراه، كلية التربية للبنات، الرياض.

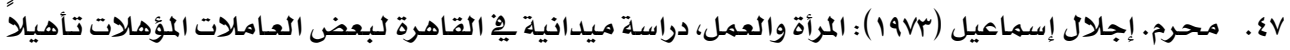
عالياً، رسالة ماجستير، قسهم إدارة المنزل، كلية الاقتصاد المنزلي، جامعة حلوان.

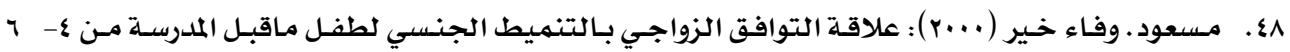
سنوات، رسـالة مـاجستير، قسم الدراسـات النفسية والاجتمـاعيـة، معهد الدراسـات العليـا للطفولـة، جامعـة عين شمس.

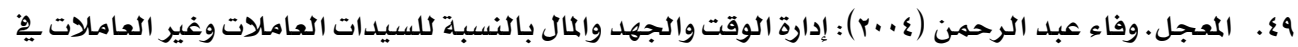

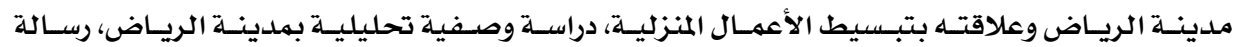
ماجستير، كلية التربية للاقتصاد المنزلي والتربية الفنية، بـالرياض. •0. مليبـاري. نجاة عبدالله (1999) ): إدارة المرأة المتعلمهة العاملة وغير العاملة لمورد الوقت وأثر ذلك على على تنشئسة

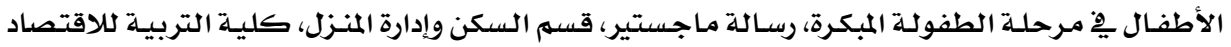
المنزبي والتربية الفنية بجدة. موسى. منى حامد (1999) ): أثر استخدام بطاقات الائتمان على إدارة الدخل المالي للأسـرة السعودية، دراسـة ميدانية بمحافظة جدة، رسالة ماجستير ، كلية التربية للاقتصاد المنزلي والتربية الفنية بجدة.

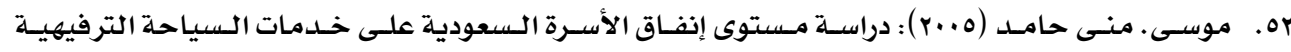
وعلاقتته بتخطيط موردها المالي، دراسـة ميدانية بمنطقة مكة المكرمسة، رسـالة دكتوراه، قسم السكن وإدارة المنزل، كلية التربية للاقتصاد المنزلي بهكة المكرمـة.

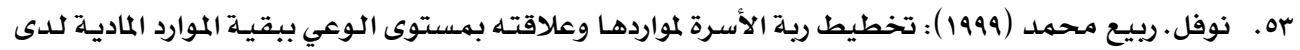
أبنائها تلاميذ المرحلة الإعدادية، رسالة دكتوراه ، كلية الاقتصاد المنزلي، جامعة المنوفية.

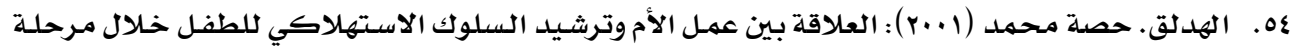
التعليم الأسـاسي، رسالة ماجستير ، كلية التربية للاقتصاد المنزلي والتربية الفنية بالرياض. ثانياً: المراجع الأجنبية: الإسني،

55. Beuttler, I. f. \& Meson, J. W. (1987): Family Cash- Flow of Dissertation, for Master's., Department of Family Sciences, Brigham Young University

56. Fanning, M. J. (1981): Home Economics Teachers, perceptions of family through four Conceptual frameworks, Education Home Economics University of Wisconsin Madison. Dissertation abstracts International. Vol.42, No.2.

57. Gorva, V. T.(1996): Family Economic Crisis and Survival in The Light of Futures; Finnish Society for Future Studies, Vol 85, No 61. 
58. Haum, I. (1976): The Working Mother, A Review of Research Child Development, Vol 34, No 3.

59. Heffernan, C (1982): Determinates and Patterns of Family Saving. Journal of Home Economics Research, Vol 11, No 1.

60. Jeffry, L. (1991): Marital and night Couples: the Effect of Wake and Sleep Patterns am Marital Adjustment, Journal Articles Vol 2, No 4.

61. Maxwell, K. \& Sisgold, S. \& Chesus, T. (1992): Richer Then You DreamedHow to make control of your two, income Family's Finances, Clarkson potter publishers, New York.

62. Ozer, E. M. (1992): Managing Work and Family, the Effect of the Child Care Responsibility on Perceived Self Efficacy and the Psychological Helthon new Working Mothers, Stanford University.

63. Patricia, M. T. \& Alyce, M. F.\& Tahiral, K. H. (1989): Net Work and Financial Satisfaction of Household Many Managers Competencies, Department of Family and Consumer Sciences Education. Iowa state University.

64. Ronald, B. (1976): Marital Adjustment and Work Problems, Comparison of The Correlation across Subsamples. Journal Articles, Vol 40, No 20.

65. Srendlove, D. (1990): Marital Adjustment among houses Ttoff and New Attorneys, Academic Medicine, Journal Articles Vol 20, No 14.

66. Ujang, W. S. \& Tahirak, H. K (1992): Credit, Saving and insurance Satis faction with preparation for financial Emergencies Among Rule House holds, Department of Human development Family Studies, Lowa State University. 